\title{
Artık Toplayıcılar ve Ben Filminde Seyircisinin Yaşam Gücünü Arttıran Bir Görüntü Toplayıcısı Olarak Agnès Varda
}

\author{
Ersan Ocak*
}

Özet

Agnès Varda'nın Les Glaneurs et la glaneuse (A(r)tık Toplayıcılar ve Ben, 2000) belgesel filminin ayırt edici niteliklerinden biri, filmin seyri esnasinda ve sonrasinda (sinema salonundan ayrildiktan sonra ve ilerleyen zamanlarda filmi hatırladıkça) seyircisinin yaşam gücünü artırmasıdır. Bu metinde, söz konusu belgesel filmin seyircisinde yaşam gücünü artıran kaynaklardan ortaya konabilen üçü tartışılacaktır. Bunlar, sırasıyla, Varda'nın bu belgesel filminde kendini "görüntü toplayıcı kadın sinemacı" olarak konumlaması; yaşamı boyunca gelişstirdiği ve cinécriture (sineyazı) olarak adlandırdığı sinema yapma biçiminin kurucu nitelikleri; ve son olarak, filminin özneleri ve seyircisiyle kurduğu özgün ilişkilerdir.

Varda (2000b) "dolanan bir yol filmi" (wandering-road-documentary) olarak tasarladiğı bu belgeselinde karşılaşmalara ve diyaloğa açık kalır. Her bir sosyal aktörle yaşadığı karşılaşmada kendini gözden geçirir; karşılaştığı sosyal aktörün anlatılarını, kendi bedeni, düşünceleri, duyguları üzerinden akıtır. Birlikte ürettiği sanatçılarla yola çıkar; karşılașmalar içinde diyaloğa girdiği sosyal aktörlerin filmini yapılandırması için onlara yer açar; seyircisinin filminin içine girebilmesi için aralıklar bırakır; özdüşünümsellik içinde kendini aşındırarak filmini kurgular. Varda duygularına dair ifadelerini ve bedeninin imgelerini bu filme dahil ederek yaşamın akışına, zamanın yıpratıcı etkisine, ölümün gelişine dair düşüncelerini gözden geçirir.

Anahtar Kelimeler: Agnès Varda, artık toplayıcılık, yaşam gücü, sineyazı (cinécriture), belgesel

* TED Üniversitesi, Şehir ve Bölge Planlama Bölümü

ORCID ID : https:/ / orcid.org/ 0000-0003-2514-3596

E-mail : ersanocak@gmail.com

DOI: 10.31122/Sinefilozofi.633092

Geliş Tarihi - Recieved: 15.10 .2019

Kabul Tarihi - Accepted: 01.12.2019 


\title{
Agnès Varda as an Image Gleaner, Who Increases the Vital Force of Audience in Gleaners and I Movie
}

\author{
Ersan Ocak*
}

\begin{abstract}
One of the distinctive features of Agnès Varda's renown documentary film Les Glaneurs et la glaneuse (Gleaners and I, 2000) is its potential to give vital force to the audience (after the screening and at times it is recalled). In this article, three resources of this vital force will be discussed. These are claimed to be the positioning of Varda herself as "an image gleaner woman filmmaker" within her own documentary; the foundational characteristics of her way of filmmaking that she developed along her life and named as cinécriture (cinewriting); and authentic relationships built up between the film and its audience, respectively.

Varda stays open to encounters and dialogue in this "wandering-road-documentary" (Varda, 2000b). She reconsiders her body, thoughts and emotions at each encounter with the narratives of the social actors of her film. She departs to the road with the artists in collaboration; opens space in her film to the social actors whom she has gone into dialogue during encounters; creates intervals to her audience to be able penetrate into her film; edits the film by eroding herself in a self-reflexive manner. While she includes expressions of her emotions and images of her own body into this film, she reconsiders her thoughts on the flow of life, eroding effect of time, and coming of death...
\end{abstract}

Keywords: Agnès Varda, gleaner, vital force, cinewriting (cinécriture), documentary

* TED Üniversitesi, Şehir ve Bölge Planlama Bölümü

ORCID ID : https:/ / orcid.org/ 0000-0003-2514-3596

E-mail : ersanocak@gmail.com

DOI: 10.31122/Sinefilozofi..633092

Geliş Tarihi - Recieved: 15.10.2019

Kabul Tarihi - Accepted: 01.12.2019 


\section{Giriş}

Agnès Varda gibi üretken olduğu kadar yaratıcı da olan yönetmenlerin yaptıkları filmlerin kaynaklarına dair bir arayış, her farklı bakış açısıyla yeniden üretilerek, zamanla sürekli genişleyen bir çalışma alanı oluşturabilir. Ben de bu metinde, Agnès Varda'nın Les Glaneurs et la glaneuse (A(r)tık Toplayıcılar ve Ben, 2000) belgesel filmine dair üç farklı bakış açısı kurarak bu filmin seyircisine hissettirdiği yaşam gücünün üç farklı kaynağını ortaya koymaya çalışacağım. Diğer bir deyişle, bu metnin kapsamını üç farklı bakış açısı ile sınırlandıracağım; bu bakış açılarından ortaya koyacağım yaşam gücü kaynakları ile de sınırlı bir sonuca varmaya çalışacağım.

Söz konusu bakış açılarını, A(r)tık Toplayıcılar ve Ben filminin adlandırılma biçiminden ve kurulum (establishment) sahnelerinde Varda'nın yaptığ 1 bir seri performanstan yola çıkarak yapılandırıyorum. Tabii ki sonrasında filmin bütününü gözden geçiriyorum. Filmin başlangıcında, Agnès Varda, Fransa'da a(r)tık toplayıcılı̆̆ın soykütüğünü sanat tarihi içinde resimli sözlüklerde arar, ondokuzuncu yüzyılda Fransa' da yapılmış artık toplayıcı resimlerinden birkaçını gözden geçirir. Geçmişte artık toplayıcılığı yapmış sosyal aktörlerle görüşür. Jules Breton'un 1877 tarihli ünlü La Gleaneuse (Kadın Artık Toplayıcı) tablosu önünde bir canlı tablo (tableau vivant) performansı yapar. Böylelikle, Varda, aşağıda her birini ayrı ayrı tartışacağım üç mesele ortaya koyar: Filmi içinde kendini nasıl konumladığını, bu filmi yapma biçimini, filmin özneleri ve seyircisiyle nasıl ilişkiler kurduğunu seyircisine hissettirir.

\section{La Glaneuse - Kadın A(r)tık Toplayıcı}

2000 yılında gösterime girdiğinde, Agnès Varda'yı dünya çapında bilinen bir yönetmen haline getiren ${ }^{1}$ A(r)tık Toplayıcllar ve Ben (Les Glaneurs et la glaneuse) filminin adina dikkat etmeli. Varda, filmlerini adlandırırken sözcük oyunları yapmaya eğilimli bir yönetmen (Kline, 2014: xviii). Fransızcada ad sözcüklerin eril veya dişil olmalarına bağlı olarak, filmin adını Türkçeye bire bir şöyle çevirmek mümkün: Erkek A(r)tık Toplayıcılar ve Kadın A(r)tık Toplayıcı (Olarak Ben) ${ }^{2}$ (Conway, 2015: 74). ${ }^{3}$ Bu bire bir çeviriden hareketle filmin kurulum sahnelerine baktığımızda iki şey söyleyebiliriz.

Varda'nın filminde sergilediği gibi, 19. yüzyılda, Fransa'da, Jean-Francois Milet, PierreEdmond Alexandre Hedouin, Jules Adolphe Aimé Louis Breton gibi ressamlar “artık toplayıcılar resimleri" yapmişlardır: Millet'nin 1857 tarihli Les Glaneurs (Kadın Artık Toplayıcılar) adlı tablosunda; Hédouin'in 1852 tarihli, Les Glaneuses fuyant l'orage (Fırtınadan Kaçan Başakçılar ${ }^{4}$ ) adlı tablosunda; Breton' un 1859 tarihli, Le rappel des glaneuses (Calling in the gleaners; Başakçllara

\footnotetext{
${ }^{1}$ Agnès Varda ilk filmini (La Point Courte) 1955 yılında yapar. Yıllar içinde çok sayıda film üretmesine rağmen yalnızca belli çevreler tarafından bilinen bir yönetmen olarak kalır. A(r)tık Toplayıcılar ve Ben filmi ile birçok önemli ödül alır ve popüler anlamda, yaygın tanınırlığı olan bir yönetmen haline gelir. Burada dikkate değer olan, bu filmin popülerleşmesi ile daha önce Varda'nın işlerini hiç bilmeyen bir seyirci kitlesinin onun sineması ile tanışmasıdır (Bénézet, 2014: 118). Öte yandan, Kline'a göre (2014), Varda'nın popüler filmlerin peşinden koşan seyirci tarafından daha az tanınmasının, bilinmesinin nedenlerinden biri, onları özellikle "ahlaki" açıdan tatmin edecek (hatta arındırıp rahatlatacak) filmler yapmak yerine, filmlerinde sürekli olarak psikolojik ve ahlâki sorular ortaya koymasıdır (xixii). Varda, seyircisini belli meseleler üzerine düşünmeye, duygularını gözden geçirmeye kışkırtmakla kalmaz, ara sıra onları öfkenlendirir...

${ }^{2}$ Fransızca-Türkçe çeviride kaybolan bu duruma dikkatimi çeken Kenan Alpdündar'a; Varda filmleri veya metinleri içinde Fransızca çeviriye ne zaman ihtiyacım olsa bana yardımcı olan Berivan Eliș'e çok teșekkür ederim.

${ }^{3}$ Filmin adındaki bu özel durum, İngilizce adlandırmanın “Gleaners and I" (A(r)tık Toplayıcılar ve Ben) olarak yapılmasına neden olur. Böylece filmin Fransızca özgün adındaki dile dayalı ince oyun İngilizce çeviride kısmen korunabilir (Chrostowska, 2007: 121). Aynı durum, Türkçe adlandırma olan “Artıkçılar ve Ben” için de geçerlidir.

${ }^{4}$ Türkçede, "(t)arlalarda kalmış başakları veya bağlarda dökülmüş meyveleri toplayan kimse" ye "başakçı" denir (TDK çevrimiçi Güncel Türkçe Sözlüğü).
} 
Çağrı) adlı tablosunda tarlalardaki artığı toplayan kadınlar gruplar halinde görülür. Breton'un 1877 tarihli ünlü La Gleaneuse (Kadın Artık Toplayıcı) tablosunda ise tek başına bir kadın artık toplayıcı çerçeveyi doldurur. Kadın artık toplayıcının tekilliğiyle istisnai bir durum oluşturan bu resim diğerleriyle birlikte düşünüldüğündeyse, sanki diğer resimlerin içinden çıkarılmış bir detay plan hissi uyandırır. Bu resimlerde temsil edildiği haliyle, Fransa' da tarihsel olarak o dönem, hasat sonrası buğday tarlalarında kalan artığı toplayanlar kadınlardır ve bu eylemi topluca yaparlar. Varda, daha filmin başında, bugün a(r)tık toplayıcı̆̆ın çoğunlukla tek başına, yalnız yapılan bir edim haline geldiğini; şehirlere yayılarak genişlediğini; erkeklerin de a(r) tık toplayıcılık yapmaya başladığını belirtir. Bu anlamda, filmin geri kalanına bakıldığında, günümüzde a(r)tık toplayıcılığın Fransa'nın çok farklı yerlerinde, çok farklı biçimlerde yapıldığı görülür. Yani, Varda, filminin bütününde bize, içinde yaşadığımız küresel tüketim çağında toplayıcılığın anakronik bir pratik olarak varlığını çok farklı görünümlerde artarak sürdürdüğünü gösterir (Cruickshank, 2007: 119).

Filmin adının Fransızcadan Türkçeye bire bir çevrilmiş halinde (Erkek A(r)tık Toplayıcılar ve Kadın A(r)tık Toplayıcı Olarak Ben) Varda'nın kendini “a(r)tık toplayıcı bir kadın” olarak nitelediği açıktır (McFadden, 2014: 52-53). Peki, Varda nasıl bir kadın a(r)tık toplayıcıdır? Bu soru bağlaminda, filmin kurulum sahnelerine dair düşünmeyi sürdürdüğümüzde, ikinci bir şeyi fark ederiz: Varda, filmin kurulum sahnelerinin sonuncusunda yaptığ (tableau vivant) performansı ile, filmi içinde bir "a(r)tık/görüntü toplayıcı kadın yönetmen" olarak kendi pozisyonunu açık eder..$^{5}$ Jules Breton'un 1877 tarihli La Gleaneuse (Kadın Artık Toplayıcı) resmini Arras Güzel Sanatlar Müzesi'nde ziyaret eder, bu tablonun yanında bir canlı tablo performansı yapar: Muhtemelen müze çalışanı olan iki erkeğin tuttuğu bir duvar halısı önünde, Breton'un resmindeki artık toplayıcı kadının yaptığı gibi, sol eliyle sağ omuzu üzerinde başaklar tutar ve kameraya poz verir. ${ }^{6}$ Seyirci olarak bizler, Breton'un modeline baktığı biçimde bakarız Varda'ya. Bir süre sonra aniden omuzundaki başakları yere bırakır ve daha önce kadraj dışında olduğu için görmediğimiz sağ elindeki dijital kamerasını kaldırıp kameranın bakacını gözüne dayar, kamerayı bize (yani onu çeken kameraya) doğrultur. Tam bu anda, "kendisi de bir toplayıcı olarak filmin ortasına yerleşir" (Gökçe, 2018: 49). Breton'un kadın artık toplayıcısı temsilini kendi bedenine taşıyarak yeniden hayatın içine sokar (McFadden, 2014: 53). Böylelikle, Fransa' da tarihsel olarak süregelen kadın artık toplayıcılığının bir parçası olduğunu ama bunu yeni bir toplayıcılık formu içinde, bir "görüntü toplayıcısı" olarak yaptığını bu performans ile ilan etmiş olur. Evet, Necati Sönmez' in de (2018) ifade ettiği gibi, Varda "hayatın çöplüğünü karıştıran bir 'görüntü toplayıcısı'" dır (40). ${ }^{7}$

Varda, A(r)tık Toplayıcılar ve Ben filmi boyunca "toplayıcılığın çok farklı biçimlerini" görüntüler olarak seyircisine sunmakla yetinmez, özellikle bu görüntülerin toplayıcısı olarak kendi varlığını maddi olarak ortaya koyar (McFadden, 2014: 52-53). "Mülakat verenleri, patatesleri, çöpleri, sanat işlerini ve buluntu nesneleri nasıl bir araştırmacı anlayışla kayıt

\footnotetext{
${ }^{5}$ Bu sahneye ek olarak, Varda'nın "a(r)tık/görüntü toplayıcı kadın yönetmen” olarak kendi pozisyonunu açıkça ortaya koyduğu diğer bir sahne, Japonya seyahatinden evine döndüğünde çantasını boşaltma sahnesidir.

${ }^{6}$ Varda daha önce Bellini'nin resmi önünde çektiği profilden fotoğrafıyla (Autoportrait a Venise, parmi quelques hommes de Genitle Bellini) yaptığı özportre çalıșmasını, bu sefer, A(r)tık Toplayıcılar ve Ben filminde, Jules Breton'un Arras Güzel Sanatlar Müzesi'nde asılı olan La Glaneuse tablosu önünde gerçekleştirir (Calatayud, 2002: 114). Bu bağlamda, A(r)tık Toplayıcılar ve Ben filminde özel olarak bu sahne, genel olarak da filmin bütününe yaygın bir özportre çizme halinin Varda'nın sanat işlerinde tarihsel bir süreklilik gösterdiği söylenebilir. Calatayud'a göre (2002) A(r)tık Toplayıcılar ve Ben filmindeki bu sahneyi, Varda'nın ele aldığı konuyla ilgili bilinen belli resimlerin görünümleriyle kaynaşma arzusu; filmin bütününü ise, Varda'nın bir sanatçı olarak ayırt edici özelliklerini, niteliklerini gösterme arzusu olarak okumak mümkündür (114).

${ }^{7}$ NecatiSönmez gibi ben de, Agnès Varda'nın filmik materyal toplayışını “ görüntü toplayıcılığı” olarakadlandırırken, Calatayud (2002), Varda' nın "kendini imgeleri yığarak biriktirmeye verdiğini" (accumulating images) ifade eder ki bu ifade Varda'nın film tasarımı ve çekim ekonomisini oldukça iyi açıklar (116). Bu bağlamda, Varda' ya "görüntü toplayıcısı" derken, onun görüntüleri birbiri üzerine yığarak biriktiren bir sinemacı olduğunu düşünebiliriz...
} 
altına alıyorsa, kendi bedenini de filmin bir meselesi ve maddesi olarak" seyircinin filminden toplayacağı șeyler arasına dahil eder (McFadden, 2014: 53). Filmin hem konu öznesi/maddesi hem de yapıcı öznesi olur. Böylelikle, Varda, A(r)tık Toplayıcılar ve Ben filminin görüntülerini, bu görüntülerin yaratıcısı olarak kendini, bedenini ve filmin yaratım sürecini bir araya getiren bir artistik pozisyon alır (McFaden, 2014: 53). ${ }^{8}$

Filmin bütününe baktığımızdaysa, Varda'nın "görüntü toplayıc1" pozisyonunu genişlettiğini, çoğalttığını görürüz. Varda, basit bir özgönderimselliği (self-referentiality) aşan biçimde, daha önce yaptığ filmlere döner ve "çoğu kendi işlerinden, topladı̆̆ ' $a(r)$ tıkları' dönüștürerek yeniden kullanması"nı çok iyi bilir, uygular (Onaran, 2018: 53). Bu anlamda, onun sineması kendi metinleri arasında bir dokuma barındırır. Varda'nın filmlerini seyrederken, bazı görüntüleri doğrudan bir önceki filminden aldığını fark edebilir ya da önceki bir filmine referans veren benzer bir görüntüyü kullandığını ayrımsarsınız. Sonuçta, Varda'nın sinema yapma biçiminin kurucu unsurlarından birinin, kendi filmografisini sürekli kendi içinde yeniden ürettiği özgönderimsel bir görselliklerarasılık (intervisuality) olduğu söylenebilir. ${ }^{9}$ Kendi ürettiği ve geride kalmış işlerini bir artık rezervi gibi kullanmanın yanı sıra, sinemanın endüstriyel standartları içinde kabul edilemez bulunan, atık olarak görülen filmik materyalleri bile değerlendirmeye çalışır. A(r)tık Toplayıcılar ve Ben filminde, küçük el kamerasını kayıtta unutarak yürüdügüüde ortaya çıkan sallanan lens kapağı görüntülerini caz müziğine eşleyerek kurguladığı sahne buna çok iyi bir örnektir. Bu sahneye "lens kapağının dansı" ("la danse du bouchon de l'objectif") adını vermiștir (Cruickshank, 2007: 124).

Cruickshank (2007), A(r)tık Toplayıcılar ve Ben filminin bütünü içinde Varda'nın zaman zaman kamerasını kendine çevirmesine, özellikle de yaşlanan bir özne-konu olarak ellerine (elinin kırıșık cildine, kamera lensinin diyaframı gibi ellerini biçimlendirişine, dijital kamerasını kullanan ellerine) doğrultmasına dayanarak onu yaşlanmanın doğal süreci üzerine düşünen bir "sinemacı a(r)tık toplayıcı" (filmmaker-gleaner) olarak adlandırır (119). Chrostowska (2007) ise, Varda'y1 "cinéglaneuse" (sinetoplayıc1) olarak adlandırırken, onun dünyayı topyekun dönüştüren, ince ince tasarlanmış fantezilerle seyirciyi cezbetmeye dayalı yerleşik sinema anlayışından uzak bir konumda, "belgeselci-denemeci" olarak kendini dönüşüme açık tuttuğunu, buluntu imgelerle seyircisini kuşattığını belirtir (130).

Yukarıda söylediklerimi toparlayacak olursam, Varda, yaşlandıkça toplumsallığın ve

\footnotetext{
${ }^{8}$ Varda'nın filmine fiziksel olarak ellerine dair çekimleri, saçlarını tarama görüntülerini koymasının kendini sahnelemenin ötesine geçen nedenleri vardır. McFadden'in (2014) Varda'nın verdiği mülakatlardan yaptığ alıntılara dayanarak bu nedenleri şöyle sıralayabiliriz: Varda kendini sahnelememiş, kendi yaptığ1 filme girmiş, katılmıș, dahil olmuștur. Filmindeki sosyal aktörlerden samimiyet beklerken kendisinin de samimi biçimde fikirlerini, duygularını aktarması gerektiğini fark etmiştir. Belgeselci olmanın yanı sıra oldukça yaşlanmış olması nedeniyle de fikirlerini, duygularını filmine dahil etmek istemiştir. Bedenine dair çekimleri yaparken yalnızdır ve not alırcasına kameraya konuşur; bir elinde kamera diğer elini çekerken doğaçladığı bir anlatı ortaya çıkarır; filmi yapan olarak filme alınmaktan küçük bir haz duyar. (aktaran McFadden, 2014: 54-55). Öte yandan, belgeselin ötekilere dair bir tür olarak kabul edilmesi nedeniyle, filmine kendini dahil etmesi, belgesel seyircisinin yerleșik algısı ve kanaatleri açısından paradoksal ve gergin bir durum yaratır.

${ }^{9}$ Bu bağlamda, Calatayud (2002) Varda'nın A(r)tık Toplayıcılar ve Ben filminde daha önceki filmlerinden doğrudan veya benzer biçimde kullandı̆̆ birçok sahneyi sayar döker: "1980 yapımı Murs murs filmindeki toplayıcılar ve üzüm koparıcıları (grape pickers) - yerden eğilip toplamakla daldan koparmak arasında fark olduğu filmde vurgulanır veya Sans toit ni loi (Çatısız, Kuralsız, 1985) filminin başında Mona'nın üzüm bağlarında üzüm koparışı; La pointe courte (1955) filminde balıkçıların midye, istiridye arayışları; L'Opéra Mouffe (1958) filminde, Paris'te Mouffetar Sokağı'nda sürten çulsuz meteliksizler; Les créatures (1965) ve Jacquot de Nantes (1990) filmlerinde göründüğü haliyle Loire Nehri halicindeki Noirmoutier Adas1; Daguerréotypes (1974-75) filminden sihirbaz Mystag'in elleri; L'une chante l'autre pas (1977), Documenteur (1980-81) veya Sans toit ni loi (Çatısız, Kuralsız, 1985) filmlerinden bazı replikler. Ulysse (1982) filmindeki keçi leşi de, A(r)tık Toplayıcılar ve Ben filmindeki koyun leşi ile titreşime girer" (Calatayud, 2002: 116-117).
} 
sanatın kenarına kıyısına itilmeye direnerek, kendi bedeninin yaşlanma imgelerini filmine dahil eden; sinemanın endüstriyel standartları dişında kalan görüntüleri dönüștürerek yaratıcı biçimde kullanan; yaşam boyu yaptığı filmlerden ve diğer sanat işlerinden arta kalanları sürekli yeniden değerlendiren; vardığı noktada biriken düşüncelerini ve duygularını derleyip toplayan bir 'a(r)tık/görüntü toplayıcı kadın sinemacı' olarak konumlar kendini. Peki bu konumlama içinde filmini nasıl bir teknikle yapar? Ne tür üretim ilişkileri içindedir, nasıl bir üretim biçimi kullanır, geliștirir?

\section{Varda'nın Film Yapma Biçimi: Cinécriture (Sineyazı)}

Varda A(r)tık Toplayıcılar ve Ben filmini yaptığında, Fransa'da küresel tüketim meselesi ciddi şekilde tartışılır hale gelmişti. Öte yandan, Fransız belgeseli, 1950'lerden beri, sosyal aktivizm ile ilişkilendirilerek ele alınıyordu (Cruickshank, 2007: 120). Bugün A(r)tık Toplayıcılar ve Ben filmi tekrar gözden geçirildiğinde, Varda'nın bu filminde belli bir tarihsel bağlamdaki siyasi, sosyal durumu basitçe yansıtmayı aşan, Fransız belgesel sinemacılığının sosyal aktivist yanına takılıp kalmayan genişliğe ve derinliğe sahip bir film yapmış olduğu ortadadır. Öte yandan, bu filmin başarılı olmasında, o dönem Fransa' da - politik meselelere dair duyarlılığın artması ve gerçekçiliğe dönüşün yükselmesine bağlı olarak - belgesel sinemanın eski gücüne ulaşmasının da payı vardır (Bénézet, 2014, 118).

Bu noktada, genel olarak Varda' nın film yapmaya dair nasıl bir yaklaşım geliștirdiğinin, özel olarak ise $A(r)$ tık Toplayıcılar ve Ben filminde kullandı̆̆1 tekniklerin bir analizini yapacağım. Böylelikle, onun bu filmiyle seyircisinde yarattığı yaşam gücünü artırma etkisini, duygulanımını, bu filmi yapma biçimi ve kullandığı teknikler üzerinden ortaya sermeye çalışacağım.

Varda, film yapma biçimini, belgesel ve kurmaca türü ayrımı yapmaksızın, cinécriture (sineyazı) olarak adlandırır (Cruickshank, 2007: 120). Sineyazı, Alexander Astruc'un camera stylo (kamera kalem) kavramı ile benzerlikler gösterse de bu kavramsallaștırmadan farklıdır. ${ }^{10}$ Ayrıntılara girmeden temel farkı söyleyecek olursak, Astruc "kamera-kalem" kavramında sinemayı edebi yazının dilselliği ile benzeșimi üzerinden kurgularken, Varda "sineyazı" da sinemanın görsel-işitselliğinin üretim biçimine, tekniğine ve sürecine dair bir kavramsallaştırmaya yönelir.

Sineyazı yaklaşımı içinde film yapan kişiye 'sineyazar' dersek, bu da aklımıza "auteur" kuramı içindeki "yaratıcı yazar-yönetmen" figürünü getirebilir. Varda, auteur kuramını üreten Cahiers du Cinema dergisi çevresinin yakınında bulunsa da, hatta bu dergi yazarları ve yönetmenleri tarafından icat edilen Fransız Yeni Dalgasının erken örneği sayılan La pointe courte (Paralel Yaşamlar, 1955) filmini üretmiş olsa da, sineyazar figürü, auteur kuramının

\footnotetext{
${ }^{10}$ Astruc 1948 yılında yazdığ “ "The Birth of a New Avant-Garde: La caméra-stylo" başlıklı makalesinde "kamera-kalem" kavramını ortaya atar. Bu makalede, sinemanın tarihsel olarak geldiği noktada, yeni bir ifade aracı olarak yükselmeye bașladığını, yavaș yavaș, adım adım, derece derece "bir dil olageldiğini" söyler. Astruc dille bir biçimi kasteder. Bu görsel-işitsel dil biçimiyle "sanatçı düşüncelerini-ne kadar soyut olursa olsun -ifade edebilir; aynen çağdaş edebi deneme ve romanda yapabildiği gibi, saplantılarını tercüme edebilir" (Astruc, 1948). Astruc sinemanın bu yeni çă̆ını "kamera-kalem çağı" olarak adlandırır. Kamera-kalem anlayışıyla "sinema, görsel olanın tiranlığından, imgenin salt kendi içinliğinden (kendi için var olmasından), anlatının anlık ve somut taleplerinden peyderpey kurtulacak; yazılı dil kadar esnek ve incelikli bir yazma aracı haline gelecek(tir)" (Astruc, 1948). Böylelikle, sinema herhangi bir konuyu, herhangi bir türü ele alabilir olacaktır. Sinema ile felsefi meselelerden tutun da, psikolojik veya metafizik konulara, fikirlerden duygulara varana dek her mesele üzerine üretim yapılabilecektir.
} 
yaratıcı yazar-yönetmen figüründen farklıdır. ${ }^{11}$

Andrew Sarris, auteur kuramının eşmerkezli olarak birbirini kuşatan üç halka biçiminde formüle edilebileceğini söyler: Kuramın bütününü kuşatan dış halka, iyi bir yönetmende olmazsa olmaz olan "teknik" bilgi ve beceri; ortada kalan halka, "kişisel stil” (personal style) ki bu çoğunlukla yaratıcı yazar-yönetmenin filmlerinde tekrar eden bazı görsel-işitsel tekniklerin ve unsurların imzası haline gelmesidir; en içteki halka ise "içsel anlam" (interior meaning) denilen yaratıcı yazar-yönetmenin kişiliğiyle filminin materyali arasındaki gerilimden çıan şeydir (Sarris, 2009: 452-453). Sonuç olarak, yine Sarris'in (2009) belirttiği gibi, "auteur kuramının kendisi sürekli akış içinde olan bir örüntü kuramıdır" ve yaratıcı yazar figürü de bu sürekli yeniden yapılandırılabilir akış içinde muğlak bir deha figürüdür (453). ${ }^{12}$

Öte yanda, Varda, sineyazar figürünü oldukça materyalist biçimde tanımlar: Sineyazar, üretici bir güç olarak, üretim sürecinde gerekli seçmeleri yapan kişidir. Varda, sineyazı kavramıla, sinema yapmaya dair yazma benzeşimini kullanırken, esasen film üretim sürecinde filmin senaryosunu metinsel olarak yazan senaristi aşan bir pozisyonu işaret eder. Film yapmayı temelde bir "seçme" işi olarak görür. Sineyazıyı tanımlayan bu seçme işini Andrea Meyer'e verdiği mülâkatta şöyle ifade eder:

Oyuncu seçimi, yer/mevsim seçimi, çalışacak ekibin seçimi, yapılacak çekimlerin, kullanılacak lensin, ışığın seçimi. Kişilere, oyunculara yönelik tavrınızın seçimi. Sonra, kurgunun, müziğin seçimi. Çağdaş müzisyenlerin seçimi. Miksaj esnasında ezginin seçimi. Filmin tanıtım materyalinin, basın dosyasının, posterinin seçimi (Meyer, 2009: 201).

\footnotetext{
${ }^{11}$ Cybelle McFadden (2014), “Varda' nın ilk filmi olan La pointe courte (1955)'un stili, dış mekan çekimleri ve aktörlerin yanı sıra aktör olmayanları da kullanması nedeniyle Yeni Dalganın öncüsü sayıldığını” söyler ve Georges Sadoul'un bu filmi “kesinlikle Fransız Yeni Dalgası'nın ilk filmi” olarak gördüğünü aktarır (36). Varda'nın söz konusu filmi Yeni Dalganın öncüsü veya ilk filmi olsa da, Varda kendisini bu akımın yönetmenleri olan Cahiers du Cinema dergisi yazarları arasında görmez. Onlarla ilk kez bir araya geldiğinde, "hızlı konuşarak şakır şakır muhabbet eden ve yatak dahil her șeyin üzerine oturan bu Cahiers du Cinema oğlanlarının (Chabrol, Truffaut, Rohmer, Brialy, Doniol Volcroze ve Godard'dan bahsetmektedir) arasında tek kız olduğunu; konuşmalarını takip etmekte zorlandığını; yanlışlıkla orada olduğunu (düşündüguünü), kendini küçük ve cahil hissettiğini" söyler (Alison Smith'ten aktaran McFadden, 2014: 36). Godard'in A bout de souffle (Nefes Nefese, 1959) ve Truffaut'nun Les quatre cent coups (400 Darbe, 1959) filmleriyle bașlatılan Fransız Yeni Dalgası bir erkekler kulübüdür. Bazı eleștirmenler Godard ve Truffaut'dan önce bu sinema akımının model işini üretmiş olan Agnès Varda'yı Yeni Dalga ile ilişkilendirseler de, Geneviève Sellier'in (2010) ifade ettiği gibi "Yeni Dalga düşünürlerin, araştırmacıların (özellikle) sosyo-kültürel bakış açısından çalışmakta isteksiz oldukları bir harekettir" (176). Yine Sellier'e göre (2010), "Yeni Dalga tekil maskülen bakış açısının meşruiyetini arar" (179). Araştırmacılar, eleştirmenler Varda'yı Yeni Dalga' nın kurucu figürü olarak görmek yerine, çoğunlukla bu akımın "annesi" veya "babaannesi" olarak görmüş, ataerkil ve cinsiyetçi bir soy ilişkisi kurmuşlardır. Sonuç olarak, ne Yeni Dalga'nın erkekler kulübü mensupları Varda'yı kendilerinden biri olarak saymış ne de Varda kendisini bu grubun bir mensubu olarak görmüştür. Les plages d'Agnès (Agnès'in Plajları, 2008) filminde, Chris Marker'ın ona bu konuda yönelttiği soruya cevap verirken Varda, Jacques Demy ve Alain Resnais'yi bu gruba eklese de kendini Yeni Dalga yönetmenleri arasında anmaz (McFadden, 2014: 36-37).

${ }^{12}$ Andrew Sarris'in (2009) Truffaut'ya referansla belirttiği gibi, “auteur kuramı verili bir zaman ve mekan için tamamiyle polemiğe dayalı bir silahtı." (451). İkinci Dünya Savaşı sonrası, Fransa' da Cahiers du Cinema dergisinde yazan "gevșek dokulu bir eleștirmenler grubunca geliștirildi" ve bu kuramin o dönem Paris'te gelişmesinin tarihsel koşulları vardı (Wollen, 2004: 68). Bazin (1957), söz konusu derginin editörü olarak, auteur kuramının sağlam temeller üzerine kurulu olmadığını ama öte yandan, "Truffaut veya Rohmer'in tutkulu aşkları kadar olmasa da, auteur kavramına inandığını ve çoğu defa onların kanaatlerini paylaştığını" açıkça söyler. Bazin'in auteur kuramına dair bir diğer önemli eleștirisinin kaynağı, onun yaratıcı ile eseri arasındaki ilişkiyi bu eleștirmenlerden farklı görmesidir. Bazin (1957) yaratıcı yazar-yönetmenin kendinden menkul dehasını sorunsallaștırırken, auteur kuramı savunucularının tersine, eserin yazarı aşabileceğini de kabul eder. Auteur kuramına dair Bazin'in önemli eleștirilerinden bir diğeri, bireysel olarak auteurün öne çıkarılmasının neyle ilgili olduğu ve sınırına dairdir. Ona göre, auteurün öne çıkarılması, kültürel alanın gelişmesi ile ilgili ve daha iyiye olan yönelimin bir bileşeni olduğu sürece doğrudur. Auteurün öne çıkarılması kültürel alanı egemenliği altına almaya başlar ve tanımlayıcı temel unsur haline gelirse bu yanlıș bir yönelim olur (Bazin, 1957).
} 
Varda, tüm bu seçmeler içinde, bir yandan film yapımında teknik tercihlerini belirlerken, diğer yandan bu teknik tercihlerin kombinasyonunda stilini oluşturur. Filmik unsurlara dair seçmeleri ve teknik tercihleri sonucunda ortaya çıkan film yapma biçimine ve stiline sineyazı der. Ona göre, edebiyatçının teknik tercihleri ve yazma biçimi sonucunda oluşan üslubu ne ise film yapımında da sineyazı odur (A. Smith'ten aktaran Jackson, 2010: 123). Böylelikle Varda, bir yandan, sineyazar olarak film üretim sürecini bütünsel bir anlayış içinde düşünmek, kavramak, yapmak istediğini ortaya koyarken (Cruickshank, 2007: 120) ${ }^{13}$, diğer yandan, yaptığ1 her seçme ile sorumluluk üstlenir, etik bir pozisyon alır. ${ }^{14}$

Varda'nın iddiasını doğru anlamalı. Varda, Noel Murray'e verdiği bir mülakatta, filmlerinde belli bir kaliteyi korumaya çalıștığını söyler ve ekler: "Reklam çekmiyorum, başka kişiler tarafından önhazırlığ yapılmış filmler yapmıyorum, star sistemi ile uğraşmıyorum. Yani kendi küçük (mütevazı) şeyimi yapıyorum" (Murray, 2009). Diğer bir deyişle, Varda, endüstriyel sinemanın büyük ölçekli ve yabancılaştırıcı Fordist iş bölümünden uzak durma gayretindedir. Filmini üretirken yapılması gereken tüm işlerin içinde yer alabilme, bu işleri birlikte yapacağı kișilerle yetkin bir șekilde tartışabilecek bilgiyle donanabilme, onlarla "birlikte üretim" yapacak kadar işin içinde olabilme istencini ortaya koyar. Bu anlamda, Varda için film yapmak "insanlarla bir arada olmanın, birlikte emek vermenin, yüzlere bakıp hikayelere dalmanın bir yoludur" (Göl, 2018: 41). Böylelikle, yapmak için yola çıktığı film-fikrine tutunarak ve temel meselesinden uzaklașmadan filmini tamamlaması mümkün olabilir. Başından beri "sinema(sı)nın şekli"ni (shape of cinema) arar ve buna "sineyazı" der. Bir kez daha altını çizmeli ki sineyazı ile yalnızca senaryoyu kastetmez. Senaryonun yanı sıra mizansen, çekim ve montajı kapsayan (yapım-öncesi, yapım ve yapım-sonrasından oluşan) film üretim sürecini bir bütün olarak içine alan işlerin her birinde verilen kararlardan oluşan bütünlüklü seçmeye sineyazı adını verir (Murray, 2009).

Varda'nın sineyazısını, sinemasının görsel-işitsel yapısı içinde, bir sineyazar olarak üretim sürecinde teknik seçmelerini nasıl yaptığına, üretim ilişkilerini nasıl yönettiğine ve nasıl bir üretim biçimi geliştirdiğine bakarak değerlendirmek mümkün. Bu bağlamda, aşağıda, Varda'nın kendine ait sineyazı anlayışııı yer yer filmografisi içinden örnekleyerek, ama esasen A(r)tık Toplayıcılar ve Ben filminin temel nitelikleri özelinde tartışacağım.

\section{Varda'nın Sineyazısında Belgesel - Kurmaca İç Iç̧e Geçer}

Varda'nin kurmaca filmlerinde belgesel katmanlar, belgesel filmlerinde ise kurmaca unsurlar birbiri içine geçer. Örneğin, kurmaca filmlerinden Cléo de 5 a 7 (Beşten Yediye Cleo, 1962) filmi "Paris belgeseli üzerine resmedilmiş bir kadın portresi" dir (Sönmez, 2018: 40; Ildır, 2018: 42). Filmin kadın karakteri Cleo ile, filme beșeri bir coğrafya kazandıran Paris, geçişken bir denge içindedirler. Varda'nın ilk (kurmaca) filmi olan La Pointe Courte (Paralel Yaşamlar, 1955) filminde ise varoluşsal sorunlarla yüzleșen genç bir çiftin hikayesi ile filme adını veren küçük balıkçı kasabasındaki mahallenin sakinlerinin geçim mücadelesi ve gündelik yaşam dertleri bir birini sırayla izleyen bir salınımda akar (Göl, 2018: 41; Jackson, 2010: 125; Kline,

\footnotetext{
${ }^{13}$ Evet, Varda, film üretim sürecini bütünsel bir anlayış içinde düşünmek, kavramak, yapmak ister. Diğer yandan, filmini tümleyici (totalizing) kapalı bir eser olarak yaratmaktan hep kaçınır. Varda'nın sinemasında tümleyici olmaktan uzak, bütünsel olma tavrını sonuç bölümünde daha açık hale getirmeye çalışacağım.

${ }^{14}$ Vilem Flusser (2002), akademik tez ile deneme biçimlerini stil açısından kıyasladı̆̆ı metninde, her seçme ediminin sorumluluk meselesini barındırdığını açıkça söyler; yaşam dolu bir stil olarak denemede yazarın sorumluluğunu en çoğa çıkardığını belirtir (193). Yazarın yazdığı şeye dair tüm sorumluluğu aldığı bu etikçi tutum, Varda'nın seçmeye dayalı sineyazı tekniği için de geçerlidir.
} 
2014: ix) ${ }^{15}$. Yani, Varda bu iki kurmaca filmde, hikayelerin bağlamını oluşturan görsel-işitsel dünyayı belgesel sinemanın beşeri coğrafyası ve mekansal gerçekliğiyle kurar, belgeselin görsel-işitsel rejimleriyle kurgular.

Belgesel filmlerinde ise filmin öznelerini-ki buna kendisi de dahildir-bir oyuncu olarak kendini oynamaya, özellikle de mesleğini, toplumsal rolünü canlandırmaya yönlendirir, performanslar yaptırır. A(r)tık Toplayıcılar ve Ben filminde de, hukukçular başta olmak üzere, belli mesleklerden özneleri mesleki kostümleri içinde kendilerini oynamaya davet eder: Avukat, savcı, aşçı bu filmde mesleki kostümleriyle kendilerini oynayarak performatif biçimde öne çıkarlar. Bunların yanı sıra, teorisyen psikanalist Jean Laplanche ve ünlü ressam Louis Pons'un da kendilerini oynadıkların hissederiz. Bu oyun(cu) rejimi tercihiyle Varda, kurmaca içinde belgeseli, belgesel içinde kurmacayı barındıran; kurmacayla gerçeği birbiri içine geçiren; filmin öznelerini ve kendisini, bir özne olarak kendi olmakla, bir sosyal karakter olarak kendini oynamak arasında salınıma tabi tutan bir anlayışla filmini yapar.

Sans Toit ni Loi (Çatısız, Kuralsız: 1985) filminde ise kurmaca ve belgesel ayrıștırılamaz biçimde birbiri içine geçer. Bu film aslında kurmaca olmasına rağmen, Varda'nın en belgesel görünümlü filmlerinden biridir. Kendi bildiği gibi yaşayan Mona adlı kadın karakterin Fransa kırsalında bir hendekte bulunan cesediyle başlayan film, bu karakterle karşılaşan kişilerle yapılan mülakatlar içerir. Bu mülakatlar belgesel nitelikli görünmesinerağmen Varda tarafından kaleme alınmış replikler ve tasarlamış sahnelerden oluşur; çekimler belgesel sinemanın kaba sertliğini yansıtırken çok ince görsel hesaplarla tasarlanıp çekilmiş, montajlanmıştır. Varda bu filminde belgesel ve kurmacayı ayrışmaz biçimde iç içe geçirmiş ve belgesel-kurmaca (docu-fiction) bir film yapmıştır (Kline, 2014: xvii). ${ }^{16}$ Bu durumda, Agnès Varda' nın film yapma tekniği ve biçimi olan sineyazıyı, belgeselle kurmaca arasındaki bu geçişkenlikler, salınımlar içinde bir oyun olarak görebiliriz.

Sonuç olarak, Varda'nın filmleri - ister kurmaca ister belgesel olarak tasnif edilsinler iç içe geçmiş ikili yapıda bir sinema anlayışının ürünüdürler. Yani, Varda kendi sineyazısı içinde, filmlerini belgesel ve kurmacanın geçişken ve iç içe olduğu ikili bir zihinle üretir. Kurmaca olarak nitelendirilen filmlerinin çoğunda, ya arka planda bir belgesel film, ön planda bir kurmaca film akar ya da kurmacayla belgesel yer değiştirmeli biçimde iç içe geçer. Belgesel olarak nitelendirilen filmlerinde ise filme konu olan özneler, belirgin bir performatif anlayışla, toplumsal rollerini canlandırır, oynarlar. Varda filmleri, belgeselden kurmacaya, kurmacadan belgesele geçişler gösteren, türün ağırlığının birinden diğerine sürekli kaydığı "kontrpuan" bir anlayış sergiler. Bu anlamda, Varda'nın sinemasının akışını kontrpuan bir sinema akışı olarak

\footnotetext{
${ }^{15}$ Varda, La Pointe Courte (1955) filminin yapısını kurarken, William Faulkner'in Çılgın Palmiyeler (Mad Palms) kitabındaki "ikili şemayı" ödünç almıştır (Tyrer, 2009: 163). Faulkner, bu kitabında iki ayrı öyküyü sıralı bölümler halinde iç içe sokar. Faulkner'in Çılgın Palmiyeler kitabını Necla Aytür ile birlikte Türkçeye çeviren Ünal Aytür (2017), kitaba yazdığı önsözde, Faulkner'in 1956 yılında, Paris Reivew' da yayınlanan sözlerine referanslaVarda'nın da La Pointe Courte filminde sineyazısı içine kattığ1-Faulkner'in "kontrpuan yazma tekniği" ni şöyle açıklar: “(Faulkner) 'Çılgın Palmiyeler' ile 'Irmak Baba' bölümlerini yalnızca iç içe geçirmekle kalmamış, aynı zamanda onları kitaptaki sırasıyla yazmıştır: "'Çıılgın Palmiyeler' in ilk bölümünü bitirir bitirmez, bir şeylerin eksik kaldığını, öykünün pekiştirilmesi, müzikteki kontrpuan benzeri bir yöntemle güçlendirilmesi gerektiğini gördüm. Bunun üzerine, 'Çılgın Palmiyeler' deki öykü yeniden canlanıncaya kadar 'Irmak Baba' yı yazdım. Derken, 'Irmak Baba'nın birinci bölümünün sonuna gelince, onu bırakıp ‘Çılgın Palmiyeler'e döndüm ve gene gücünü yitirmeye başlayıncaya kadar yazmaya devam ettim. Sonra, onun antitezi olan 'Irmak Baba'nın bir bölümünü daha yazarak 'Çılgın Palmiyeler'i yeniden canlandırıp güçlendirdim"'” (Aytür, 2017: 5).

${ }^{16}$ Günümüzde, Sans toit ni loi (Çatısız, Kuralsız, 1985) filmi gibi, kurmaca olanla kurmaca olmayan sinemanın melezlenmesi üzerine kurulu filmler giderek daha fazla ilgi çekiyor. Böylelikle, Varda' nın kariyeri boyunca temel eğilimi olan "kurmaca ve belgesel sinemayı birbiri içinde eritme becerisi" (Guest, 2009: 48) bugün onun filmlerinin geriye dönük olarak yeniden seyredilmesini ve değerlendirilmesini sağlıyor.
} 
nitelemek mümkündür. ${ }^{17}$ Diğer yandan bu sinemayı, seyircinin alımlaması açısından, kurmaca ve belgeseli birbirinin antitezi olarak bir araya getiren ve her bir filmin bütünselliğinde senteze ulaşan diyalektik bir sinema olarak görmek de mümkündür. Varda'nın seyircisi iki karşıt türü zihninde diyalektik biçimde bir araya getirir ve sentezler. Varda'nın sinemasında, Bénézet'in (2014) ifadesiyle "öznel olan ve nesnel olan arasında kurulan denge"(120) onun sinemasinın diyalektik olarak alımlanmasının bir sonucudur.

Varda, tüm yaşamı boyunca sinemasını, kurmaca veya belgesel olması fark etmeksizin, gerçek dünya üzerine kurmuştur. Böylelikle sinemasında, "kurmaca ve belgesel konvansiyonları ve kategorileri arasında biricik (ona has) yaratıcı bir gerilim ve kasti bir karışıklık" hep fark edilir (Guest, 2009: 48). Kline (2014) Varda'nın sinemasının kurmaca ve belgesel arasında kalmış halini, onun sinemasının "temel çelişkisi" olarak tanımlar (xvi). Varda'ya göre, "belgesel yanı olmayan bir kurmaca yoktur, estetik niyeti olmayan bir film yoktur" (Kline, 2014: xvii).

Varda'nın sineması, temel sinema türleri olan kurmaca ve belgeseli iç içe geçirerek aralarındaki sınırı bulanıklaştırmakla da yetinmez, farklı film tarzlarını kendi içinde melezler. Bu anlamda, A(r)tık Toplayıcılarve Ben filmi için Martine Beugnet (2006), "denemenin, belgeselin, yol filminin ve güncenin bir melezi" der (4). Varda, sinema içinde yaratıcı bir oyunbozandır. Burada, Varda'nın "oyunbozanlığı", Huizinga' nın mızıkçısından (spoil-sport) veya fasulyeden oyuncusundan (false-player) farklıdır. Huizinga'nın 'devrimci' için ifade ettiği türden bir oyunbozanliktır onunki (Huizinga, 2010: 29-30). Varda, egemen film yapım anlayıșının önerdiği, derinlemesine uzmanlașmıș ve ayrıșmıș Fordist üretim biçimi ve ilișkileri içinde film yapmayı istemediğinden yaratıcı bir oyunbozanlıkla yeni bir üretim tekniğinin ve biçiminin oyun kurallarını belirler; türler arasında geçişken bir tarz edinir. Öte yandan, böyle bir yaratıcı oyunbozanlık içine girmese film yapması da büyük ihtimal mümkün olmayacaktır. ${ }^{18}$

\section{Varda Sineyazı Tekniği İçinde Deney Yapma Arzusuyla Doludur}

Varda, sineyazısı içinde, imgelerle ve seslerle deney yapma arzusuyla doludur; önden belirlenmiş yapım anlayışına uymak konusunda oldukça gönülsüz davranır (Bénézet, 2014: 111). Sürekli olarak sinemanın sınırlarında dolaşan Varda, "tek bir tarz veya yaklaşım içinde kalmayı reddeder ve bunun yerine kendini durmaksızın stilistik ve biçimsel deneyler yapmaya adar" (Guest, 2009: 49).

\footnotetext{
${ }^{17}$ Kontrpuan bir müzik terimidir. Batı çok sesli müziğinde, Bach'a kadar, armonik (alt)yapı ile melodi ayrı ayrı işler. Örneğin piyanoda icracı genellikle sol eliyle armonik (alt)yapıyı çalarken, sağ eliyle melodiyi çalar. Bach bu ayrımı, armonik (alt)yapı ve melodiyi yer değiştirerek ve birbiri içine geçirerek ortadan kaldırır. Benzer biçimde, Varda da sineyazısı ile belgesel ve kurmaca sinema arasındaki teknik, biçimsel ve içeriğe dair ayrımları birbiri içine sokarak ortadan kaldırmıştır. Öte yandan, kontrpuan edebiyatta da kullanılan bir teknik olarak karşımıza çıkar. 15 nolu dipnotta da belirttiğim gibi, Faulkner, Çılgın Palmiyeler romanını "müzikteki kontrpuan benzeri bir yöntemle" yazmıștır. Varda, ilk filmi olan La Point Courte'u (1955) yaparken, Faulkner'in söz konusu eserinden biçimsel olarak etkilenmiştir.

${ }^{18}$ Varda, yaratıcı bir oyunbozanlıkla, hayatı boyu film yapmayı sürdürebilmiştir. Bu yaratıcı oyunbozanlığı karşılık bulmuş, çok sayıda prestijli ödül de kazanmıştır. Öte yandan, bu çok ödüllü yönetmen film yapmak için gerekli parasal kaynă̆ bulmakta hep zorlanmıştır. BFI Sight \& Sound Magazine için Daniel Trilling' in (2019 güncellemeli) onunla yaptığı bir mülakatta şöyle der: "Size ödül dolabımı gösterebilirim. Tam bir dolap dolusu ödül. Fakat film yapmak istediğimde para bulamıyorum. İnanılmaz, bana güvenmiyorlar." Bu para sıkıntısını aşarak film yapmaya devam edebilmek için de yaratıcı bir oyunbozan olmak durumunda kalmış, tarihsel olarak belli bir noktadan sonra dijital teknolojinin ucuzluğundan yararlanmıș, bu teknolojinin görsel plastiği içinde sürekli biçimsel deneyler yapmiştır.
} 
Narsist bir pozisyonu sürekli sorgulatan bir aralıkta kalarak, bir eliyle diğer elini çekmesi; bedeninin maddiliği yanı sıra, sosyal aktörlere yönelttiği sorular üzerinden kendi düşünce ve duygularını sorgulaması onu "biçimsel deneyler" yapmak üzere "daha büyük bir artistik gaye"ye yöneltir (McFadden, 2014: 55). Varda'nın filmlerinin büyük çoğunluğunda dikkat çeken deneysel nitelikler, "sanatçı ile işi arasında olduğu gibi sanatçıyla yararlandı̆̆ı görsel mecralar (resim, fotoğraf ve film) arasındaki oyunlarla öne çıkar" (Chrostowska, 2007: 124).

Varda'nın sineyazısı, onun kendini düşünceleri, duyguları ve bedeni ile filmine dahil etmesinin ötesine geçer ve esasen ötekilere yöneltir. Ötekilerin duygularını, düşüncelerini, kanaatlerini, bedenlerini bitmeyen bir merakla kamerasıyla izleyen, kaydeden, sonra da kurgulayan Varda, "her şeyi mutlak olarak bilen sanatçı fikri" nden uzak durur (McFadden, 2014: 55). Böyle bir pozisyonlanma, kaçınılmaz olarak, bildiklerini sorgulayarak kullanmasını ve yararlanacağı teknikleri sürekli gözden geçirmesini gerektiren bir artistik pozisyon açığa çıkarır. Bu bağlamda, A(r)tık Toplayıcılar ve Ben filmiyle, sineyazısına dijital videoyu ilk kez dahil eden Varda, belgesel sineması içinde "yeni bir başlangıç yapar" ve "yeni anlatı biçimleri ve kipleri üzerine deneylere girişir" (Tyrer, 2009: 72-73). Dijital el kamerasını israf ve çöpe dair sosyo-ekonomik ve kültürel olguları tesbit etmek ve kaydetmek için kullanırken, aynı zamanda bu süreçte kendi toplumsal konumunu, bedenini, duygularını ve düşüncelerini kavramaya dair deneysel bir düşünme aygıtına dönüştürür. Bu aygıtı kendi bedenine çevirdiğinde, seyircisini de kendi bedeni üzerine düşünmeye yöneltir. Yaklaşan ölümle kurulabilecek serinkanlı ilişki içinde, dünyanın meselelerine bakmanın önemini hisseder ve hissettirir. Dijital el kamerasıyla beraber içine girdiği bu deneysel arayıșta, seyirciyi ötekinin sorunlarını anlama, kavrama gayreti içine sokması; seyircinin bir film izlediğine dair ayık kalmakla beraber, bir fail olarak filmin meselelerine dair düşünmeye, duyumsamaya açılması, bu filmin seyircilerin yaşam gücünü artırmada önemli bir bileșeni olur. Varda, kurnaz deneysel hamlelerle, seyirciyi film izlediğinin farkında olmakla birlikte kafasını çevirmeden, gözlerini ayırmadan filmi seyretmeye bağlar.

Delphine Bénézet (2014) onun filmlerinde ele aldı̆̆ı alışılmışın dışındaki konuları ve özneleri inceler; film yapım pratiklerine dair tesbitlerde bulunur ve Varda' nın özgünlüklerini açılamaya çalışır. Bunu yaparken, Varda'nın farklı filmlerini analiz eder. Bu filmlerden Elsa la Rose (1965) ve Uncle Yonca (1967) filmlerinin analizi sırasında yaptığı bazı tesbitleri $A(r)$ tık Toplayıcılar ve Ben filmi için de söylemek mümkündür. Örneğin, Elsa la Rose filmi deneme tarzı içinde "kurmaca, belgesel ve deneysel estetik arasında kaymalar gösterir" (Bénézet, 2014: 113). Benzer biçimde Varda, A(r)tık Toplayıcılar ve Ben filmi içinde dijital video kameranın teknik kapasitesine dair konuştuğu sahnede ve küçük el kamerasını açık olduğu haliyle kayıtta unutması sonucu üretilmiş sallanan lens kapağı görüntülerini caz müziğine eșleyerek kurguladığı sahnede - ki bu sahneye "lens kapağının dansı" ("la danse du bouchon de l'objectif") adını vermiştir (Cruickshank, 2007: 124)-olduğu gibi, kurmaca ve belgeselin yanı sıra deneysel sinemanın/videonun estetik alanına açılır. Sonuç olarak, Varda'nın bu filmindeki sineyazısı kurmaca ve belgesel türleri arası bir görsel-işitsel arayışla kalmaz, deneysel unsurlar da barındirır.

\section{Varda'nın Sineyazısı “Duygusal Yoğunluklu” Deneme Filme Ya(t)kındır}

"Sinema nedir" sorusu, Varda'nın sineyazısını belirleyen temel soru(su)dur. Bu soruyu sürekli olarak kendine yöneltirken, "sinema(sı)nın şekli"ni (shape of cinema) arar (Murray, 2009); düşünce ve duygularını eşdüzeyli ve eşzamanlı diri tutarak film yapar. "Sineyazı" anlayıșını bu soru üzerinden ortaya atar ve sürekli yeniden tanımlar. 
A(r)tık Toplayıcılar ve Ben filminde, Varda, Étienne-Jules Marey'in tüfek biçiminde tasarladığı kamerasıyla kuşların uçuş hareketlerini saptadığı yer olan Domaine de la Folie'yi ziyaret eder. Bu ziyarete dair görüntüleri, Varda'ya sinemanın ne olduğunu ve kendisinin sinema tarihi içindeki yerini sorgulatır (Calatayud, 2002:117). Marey'in ürettiği imgeleri yeniden gözden geçirirken, Varda, "sinematik konu maddesinin hep aynı olduğunu (manzaralar, insanlar ve hayvanlar) ve her bir sinemacıyı diğerinden ayıranın onların sineyazısı olduğunu fark eder" (Calatayud, 2002: 117).

Varda sineyazısıyla Alain Resnais, Chris Marker, Marguiret Duras ve Jean-Luc Godard'a daha yakındır. Adı geçen bu yönetmenleri, en genel düzeyde, deneme filme ya(t)kınlıkları bir araya getirebilir. Guest'e (2009) göre, bu ya(t)kınlıkları içinde söz konusu yönetmenlerin filmlerinde şu benzer nitelikler görülür: Bu yönetmenler, fotoğrafın büyüsüne kapılmış bir halde görüntünün anlatı sınırlarını genişletir, ${ }^{19}$ edebiyata sıkı sıkıya tutunurken özellikle edebi denemeyi görsel-işitsel olarak sinema içinde yeniden üretme gayretiyle biçimsel karmaşıklı̆̆ zorlarlar. Öte yandan, deneme film olarak adlandırılan türün çoklu niteliklerinin kombinasyonu ve derecesi bu yönetmenlerin her birinde farklıdır. Yani, bu yönetmenlerin her birinin deneme filme meyleden sineyazısının bileșenleri diğerininkinden farklı bir bileşime sahiptir. $\mathrm{Bu}$ yönetmenlerin deneme filmleri, bir fikrin etrafında dolaşırken, öngörülemez biçimde bu fikrin karşısına dikilen bir tavır alabilir; entelektüel ve felsefik bir titizlikle karmaşık bir ritim kurabilir; filmin çoklu katmanlarını bir yandan teker teker açarken, diğer yandan birbirleriyle dokuyabilirler. Varda, yakınında durduğu bu yönetmenlerin deneme filmlerinin yukarıda sıraladığım temel niteliklerine özgün bir katkı olarak, kendi (deneme) filmlerine "duygusal bir yoğunluk ve derinlik" katar (Guest, 2009: 46). ${ }^{20}$ Deneme filmin öznelliği, özeleștirselliği ve özdüşünümselliği içinde Varda, Japonya seyahati sonrası evine varış sahnesinde, kendi sineyazı anlayışını bize teşhir eder. Calatayud (2002) bu sekansın A(r)tık Toplayıcılar ve Ben filmi içinde ayrı bir film gibi çalıștığını söyler (117-118).

\section{Varda'nın Sineyazısının Temel Anlatı Stratejsi: Konu Dışına Çıkmalar, Arasözler ve Geri Dönüis}

A(r)tık Toplayıcılar ve Ben filminin basın kitinin başlangıcında yer alan "Yönetmenin Notu" bölümünde Varda (2000b), filmin esas konusunun "israf ve çöp" olduğunu, filmin öznelerininse a(r)tık toplayıcılar (kırsal alanda, hasat sonrası tarlada kalanı eğilip toplayanlar; bahçelerde, bağlarda dalından koparanlar; kentte, pazardan arta kalanlar arasından yenebilecekleri seçenler; çöpleri karıștırıp arasından ișe yararları alanlar; atılan eşyalardan kurtarabildiklerini kurtaranlar) ${ }^{21}$ olduğunu açıkça belirtir. Öte yandan, filmini örerken filmin konusuyla dolaylı olarak ilişkilendirilebilecek farklı materyalleri, izlekleri işin içine katmak ister. Filmin konusuna ve öznelerine ihanet etmeden, filmini "karșılaștığı güvencesizliğe dair duyumsadığıduygular; yeni küçük dijitalkameraların sağladığıimkânlar; kendinde(bedeninde) görebildiklerini filme çekme arzusu; ve resime olan tutkusu" ile örer (Varda, 2000b). Tüm bu

\footnotetext{
${ }^{19}$ Sinematografisinde fotoğraf bilgisi ve deneyimi hep hissedilen Varda, filmografisi içinde özellikle CineVardaPhoto Üçlemesi ile fotoğrafla sinema arasındaki geçişken yaklaşımını ortaya koyar. Üniversitede fotoğraf eğitimi alan Varda, kariyerine tiyatro fotoğrafçısı olarak başlamış, daha sonra sinemaya geçmiştir.

${ }^{20}$ Chrostowska (2007) Varda'nın A(r)tık Toplayıcılar ve Ben filminden iki yıl sonra yaptığı, bu filmin devamı niteliğindeki A(r)tık Toplayıcılar ve Ben... İki Yıl Sonra (2002) adlı filminin "değișken, çok yönlü bir tür olarak bilinen deneme filmin mükemmel temsilcilerinden biri olduğu"nu iddia eder (119).

${ }^{21}$ Toplumsal dişlananlar ve uyumsuzlar, Varda'nın filmografisi içinde zaman zaman geri döndüğü bir sosyal tiptir. Sans Toit ni Loi (Çatısız, Kuralsız, 1985) filminde Mona karakteri bu sosyal tipin şahikasıdır. A(r)tık Toplayıcılar ve Ben filminde, Varda'nın temasa geçtiği, duygularını, düşüncelerini, deneyimlerini aktardığı ahir zaman toplayıcılarına olan ilgisi, tüm filmografisi içinde zaman zaman geri döndüğü bir sosyal tip olarak toplum tarafından dışlananlara ve uyumsuzlara olan ilgisini teyit eder (Bénézet, 2014: 118).
} 
parçaların anlamlı biçimde bir araya gelebildiği bütünsel bir film yapmak için uğraşır. Bunu yaparken israfa, açlığa dair ders vermekten de, salt gözleme dayalı (kamera ve kendisi orada değilmiş gibi görünen) görüntülerle bir film yapmaktan da kaçınır. "Bunun yerine, Varda, artistik müdahale ve konu dışına çıkma (arasöz) stratejisini önplana alır" (Conway, 2015: 73). Bu anlatı stratejisini sıralandırılmış bir şemaya oturtarak gerçekleștirir. Filmin yönetmen notlarında, zihnindeki şemayı nasıl işlettiğini şöyle açıklar: Önce kırsal alanda, hasat sonrası tarlada kalan artıkları eğilip toplayanları, bahçelerde, bağlarda dalından koparanları araştırır, bulur. Ardından, kentte, pazardan arta kalanlar arasından yenebilecekleri seçenlerin, çöpleri karıștırıp arasından ișe yararları alanların, atılan eşyalardan kurtarabildiklerini kurtaranların, yani atık toplayanların peşine düşer. Sonra da, 'filmin esas konusu olan 'israf ve çöp' ile dolaylı olarak iliş̧ili olan konu dışına çıkmalar, arasözler için kendine müsade eder" (Varda, 2000b).

Ben Tyrer (2009) bu yaklaşımıyla Varda'nın A(r)tık Toplayıcılar ve Ben filmini “düzensiz görünümüne rağmen, konu dışına çıkma (arasöz) ve geri dönüş (digression and return) ilkesine dayalı olarak titiz biçimde yapılandırıldığını" söyler (161). Tyrer'a (2009) göre, karakterlerin ve yerlerin karmaşıklığına, çok sayıda farklı izleğin filme eşlik etmesine rağmen, Varda "oyundoluluğu ve dolambaçlı araştırmaları, soruşturmaları içinde" filmini bütünsel biçimde bir araya getirmeyi incelikli ve titiz bir çalışma sonucu başarır (162). Conway (2015) ise, Varda'nın yalnızca bu belgeselinde değil, genel olarak belgesellerini yaparken istikrarlı șekilde uyguladığı yöntemlerden birinin "egemen organizasyon şemasını konu dışına çıkmalarla (arasözlerle) delmek" olduğunu iddia eder (80). Benzer biçimde Bénézet (2014) Varda'nın sineyazısında tümleyici (totalizing) ve kapalı söyleme dayalı bir anlatı ve biçimden uzak durduğunu; en çok başvurduğu yöntemsel, biçimsel stratejinin "anlık, kendiliğinden konu dişına çıkmalar (arasözler)" (spontaneous digressions) olduğunu söyler (115-116). Varda'nın bu anlık konu dışına çıkmalarının kaynağı, filmin çekimleri esnasında, fikirleri ile imgeleri ilişkilendirirken kendini itkilerine bırakması, sezgileriyle hareket etmesidir. Ama iş montaj yapmaya gelince, Varda akla dayalı hareket eder, yapısal bir tavır takınır; konu dışına çıkmaları dairesel olarak ana izleğe geri bağlar (Meyer, 2009: 200). Yani, Varda, montaj aşamasında konu dışına çıkma ve geri dönüş stratejisini, yapısal bir anlayışla ve ince hesaplarla işletir.

Filmin uluslararası dağıtımının genişliği ve seyirci sayısının yüksekliği, Varda'nın konu dışına çıkış ve geri dönüşlere dayalı anlatı stratejisinin sonucu olarak filmindeki karmaşıklığın ve çok izlekli yapının seyirci tarafından kabul edildiğini göstermektedir. Varda'nın kendi bedenine ve yaşlanmasına dair özdüşünümsel çekimleri, dijital video kamera ile biçimsel deneylere girişmesi, tutkuyla bağlı olduğu resim sanatını dolaylı biçimde filmin konusuna bağlaması seyircinin filmin parçalı ama bütünsel yapısı içinde takip edebildiği izlekler olmuşlardır.

\section{Varda'nın Filmin Özneleri ve Seyircisi ile Kurduğu ilişkiler}

Varda, A(r)tık Toplayıcılar ve Ben filminin açılışında, üstses kuşağında, "filmler her zaman duygulardan kaynaklanır" der. Pazar yerinde arta kalanları yerden toplayanları, marketlerin çöp kutularını karıştıranları gördükçe, onların filmini yapmak ister. “Özellikle de onların rızası olmadan yapılamayacak olan filmi yapmak ister" ve sorar: "Biri onlara mani olmadan, onları engellemeden a(r)tık toplayıcılara nasıl tanıklık eder?" (Varda, 2000b). Varda'nın filminin kurucu sorusudur bu. Belgesel sinemacının yapacağı her film için tekrar tekrar kendine sorması gereken temel sorulardan biri, filmine konu olan öznelerle nasıl bir ilişki kurduğu, nasıl bir ilişki kurması gerektiğidir. Varda'nın bu soruyu nasıl ele aldığı ve cevapladığı, filmin özneleri olan a(r)tık toplayıcılarla nasıl ilişkiler kurduğuna bakılarak tartışılabilir. A(r)tık Toplayıcılar ve Ben filmi söz konusu olduğunda, Varda'nın filmini üretip sunduğu özne olarak seyircisiyle nasıl bir ilişki kurduğu da önemli bir meseledir. 
Așağıda ilk olarak, Varda'nın filmin özneleri olan a(r)tık toplayıcılarla nasıl bir ilişki kurduğu onlarla ilgili sahneler incelenerek değerlendirilecektir. Bir diğer özne kategorisini oluşturan seyirciler içinse şu sorulara cevap aranacaktır: Varda a(r)tık toplayıcılar üzerine yaptığ $\breve{1}$ bu filmi seyircisine nasıl sunmaktadır? A(r)tık toplayıcıları rahatsız etmeden, onlara engel olmadan bir film yapma gayretindeyken, seyircisine karşı tutumu nedir, onunla nasıl bir ilişki kurmak istemektedir?

\section{Varda Filmine Konu Olan Özneleri Rahatsız Olmayacaklar Biçimde Filminin İçine Çeker, Onlara Filmi(ni) Kurmaları İçin Yer Açar}

A(r)tık Toplayıcılar ve Ben filmine konu olan özneler, filmin akışı içinde belli bir dizgeyle sunulurlar. Varda, ilk olarak, ansiklopedilere girdi olan, on dokuzuncu yüzyıl resimlerinde temsil edilen kadın artık toplayıcıları gösterir bize; ardından çocukluklarında, gençliklerinde israfa karşı ve/ya 2. Dünya Savaşı sırasında yoksulluk içinde olduklarından mecburen tarlalardaki artığı toplayanlarla tanıştırır. Tam bu noktada, Varda filmin şimdiki zamanına geçer ve filmine konu olacak özneler açısından önemli bir tespitte bulunur: On dokuzuncu yüzyıl ve yirminci yüzyılın ilk yarısındaki anlamıla hasat sonrası tarlalarda yapılan artık toplayıcılığı bugün çok azalmış olabilir ama bütünüyle yok olmamıștır; "[k]öyde olsun, şehirde olsun yerden toplama alışkanlığı hâlâ var"lığını sürdürmektedir ve "bunda utanılacak bir şey yok"tur (Varda, 2000a: 02:40 - 02:54). Varda' nın bir diğer önemli tesbiti ise bugün toplayıcılığın kırsal alanda olduğu kadar şehirde de yapıldı̆̆ıdır. Ayrıca, tarihsel olarak kadınların yapageldiği toplayıcılığa bugün erkekler de dahil olmuştur. Varda'nın en çok dikkatini çeken şeyse toplayıcılığın giderek yalnız başına yapılmasıdır. "Oysa tablolarda gördüğümüz üzere kadın toplayıcılar her zaman gruplar halinde resmedilmiştir. Yalnız olan çok nadirdir" (Varda, 2000a: 03:54 - 04:00). Bu sekanslardan anlaş1lacağ üzere Varda, filmin geri kalanında, kırsal alandaki toplayıcıların yanı sıra kentteki toplayıcıları da filmin konu özneleri olarak kayıt altına alacak; kadın toplayıcıların yanı sıra erkek toplayıcılarla da görüşecek; kırda ve kentteki toplayıcıların yalnızlığını anlamaya çalışacaktır...

Varda, ilk olarak patates tarlalarında yapılan toplayıcılığı seyircisine sunar. Patates tarlalarındaki hasat sonrası toplayıcılık kısmen devam etmektedir. Ama daha önemlisi, Varda, yasalarla düzenlenmiş pazar standartları gereği, belli bir ölçünün altındaki ve üstündeki yenebilir durumdaki patateslerin tarlalara geri döküldügünüüğrenir. Yani, patates tarlalarında, hasat sonrası tarihsel olarak yapılan "artık toplayıcılığı" kısmen sürerken, diğer yanda, patateslerin ağırlıkları ve boylarına göre ayrıștırılması sonrası, pazar standartlarına uymadığı için, tarlalara getirilip dökülen patates "atık toplayıcılığı" ortaya çıkmıştır. Artık toplayıcıları hasat zamanında patates tarlalarını takip ederek tarladaki artık patatesleri toplarlar. Pazar standartları dışındaki patateslerin ise ne zaman, nereye atılacağı bilinemez. Ancak yiyecek yoksunluğu içinde olan yoksullar ve muhtaçlar bunu takip etmenin bir yolunu bulur (örneğin, patatesleri ayrıştıran fabrikayı gözler, atık patatesleri tarlalara taşıyan kamyonları, traktörleri takip ederler) ve atık toplarlar...2

Atık toplayıcılığını kayıt altına alırken Varda, kalp biçimindeki patateslerle karşılaşır.

\footnotetext{
22 Türkçenin bir imkânını kullanarak filmin adında ve makale boyunca "artık" ve "atık" sözcüklerini "a(r)tık" biçiminde yazarak yer yer bir arada, iç içe kullandığım okuyucunun dikkatini çekmiştir. Bunu, en başta açılamak yerine okuyucunun ilgisini diri tutmak, aklını kurcalamak, metinle tartışmaya girmesini sağlamak, kısacası Agnès Varda'dan öğrendiğim bir yöntemle okuyucuyu metne angaje etmek, ona bir yer açmak ve metni okurken zihninde yeniden yazmasını teşvik etmek için yaptım. Yukarıdaki metinde, okuyucu için artık toplayıcılığı ve atık toplayıcılığı arasındaki farkı açı hale getirebilmişimdir diye umuyorum.
} 
$\mathrm{Bu}$ patateslerin yakın çekimlerini yaparken de aklına bir fikir gelir: Pazar standartları dışında kalan patateslerin tarlalara döküldüğü bir gün "İyi Niyet Hayır Yemekleri" adlı aşevi için çalıșanlarla bir keșif yapmak. Bu keşife dahil olan așevinin gönüllü çalıșanlarının kendileri de işsizlikten ve yoksulluktan dolayı aşevinden yemek alan kişilerdir. Tarlalardan çuval çuval sağlıklı, yenebilir atık patates toplarlar. İşte bu sekanslarda yaptığı çekimler ve mülakatlarda, Varda'nın yerden topladığı için sıkıntı hisseden öznelerle nasıl bir ilişki kurduğunu görürüz. Tek ebeveyn olarak, Kızıl Haç ve Aşevi'nden beslenen bir siyahi kadın, aşevi için topladığı patatesi çocukları ve kendi için de toplamış olduğunu söyler. Sıkıntılı duruşu içinde (kendi gibi aşevinden beslenmek zorunda kalanları kast ederek) ekler: "Birlikte topluyoruz" (Varda, 2000a: 10:54 - 11:03). Așevindeki hayır yemeklerine işsiz olduğu için katılan orta yaşlı bir adam, halen işsiz olmakla birlikte yakında bir işe girme ihtimali olduğunu belirtir ve ekler: "Bu esnada, hiçbir şey yapmadan durmaktansa zor durumdaki insanlara yardım ediyorum (...) Tüm bunların (sağlıklı, yenebilir atık patatesi gösterir) çöpe gittiğini gördüğümde ve bazı insanların yiyecek hiçbir şeyi yokken, her şey gerçekten utanç verici geliyor" (Varda, 2000a: 11:04 - 11:32).

Varda, Claude'la pazar standartı dışında olduğu için atılmış patatesleri toplarken karşılaşır ve tanışır. Claude, işini kaybetmiş, eşinden boşanmış ve uzaktaki çocuklarını parası ve ehliyeti olmadığı için göremeyen bir yoksuldur. Kent dışında, bir karavanda yaşar. Claude'un şu sözü filmin önemli vurgu noktalarından biridir: "Ellerimizin kirlenmesinden korkmuyoruz. Ellerinizi her zaman yıkayabilirsiniz" (Varda, 2000a: 17:34-17:40). Francois ise, sürekli plastik çizmeler giyerek kentte dolaşan, bir işi ve sigortası olmasına rağmen on yıldır çöplerden beslenen biridir. $O$ ise insanların aşırı tüketim ve israf nedeniyle yerküreye, bitkilere, hayvanlara ve özellikle kuşlara verdiği zarara çok kızgındır. Şöyle der: "Yüzde yüz çöp kutularından topladıklarımdan yaşıyorum. Yüzde yüz çöpü on yıldır yiyorum, hiç hasta olmadım" (Varda, 2000a: 54:10 - 54:20). Solomon da kendisine evini açmış yaşlı bir adam olan Charlie Plusquec'in yanında, kentte yaşar. O ise pazar yerlerinden, çöp kutularından yiyecek toplayarak; sokağa atılan beyaz eşyaların içinden işe yarayanları seçip tamir ederek yaşamını sürdürür. Solomon bulduğu yiyecekler için şöyle der: "Piyango gibi (...) Bazen soğuk et buluyorsunuz, bazen kuş eti (tavuk, hindi, ördek), bazen ikisini birden" (Varda, 2000a: 59:20 - 59:50). Seçerek eve getirdiği makinaları uygun parça bularak tamir eder. Makina tekrar çalıșır hale gelince ya satar ya da ihtiyacı olan bir komşuya verir. Onu konuk eden yaşlı adam Solomon'u "arada sırada ortalardan kaybolan bir göçmen kuş"a benzetir (Varda, 2000a: 58:27 - 58:40). Varda'nın filminde en yoğun biçimde takip ettiği sosyal karakter ise eskiden üniversitede asistan olan, şimdi ise Paris'in banliyölerinden birinde, çoğunu Afrikalı sığınmacıların oluşturduğu bir sığınma evinde yaşayan genç erkektir. ${ }^{23}$ Geçimini tren istasyonu çıkışında dergi, gazete satarak sağlar. Pazar yerinde kalan taze yiyeceklerin bir kısmını bulduğunda orada çiğ tüketerek, geri kalan kısmını da kaldığı yere götürerek beslenir. Ayrıca sabah erken vakitte, fırınların yakınlarındaki çöplerden, bir gün önce atılan ekmeği toplar. Akşamları ise kaldığı sığınma evindeki Afrikalılara gönüllü ve ücretsiz olarak Fransızca okuma yazma öğretir. Fransız eğitim sisteminin bir parçası olmadığını ve eğitim materyallerini kendisinin ürettiğini özellikle belirtir (Varda, 2000a: 01:10:50 - 01: 14:50).

Varda, tüm bu yoksul sosyal karakterlerin kendilerini ifade etmeleri için onlara hassasiyetle yaklaşır. Așevinden beslenmek zorunda kalmış siyahi, tek ebeveyn kadını ve orta yașlı erkeği, tarlalara dökülen pazar standardı dışı patatesleri toplamak için aşeviyle organize ettikleri keşif esnasında tanır. Claude'a ise bu keşiforganizasyonu sonrasında denkgelir. Onunla tanıștıktan sonra kabul etmesi üzerine yaşadığı karavana gidip mülakat yapar. Francois'dan

\footnotetext{
${ }^{23}$ Bu genç adamın adının Alain F. olduğunu, kendisinin pazar yeri atık toplayıcısı, gazete satıcısı, öğretmen ve biyolog olduğunu, Agnès Varda'nın 2002 yapımı A(r)tık Toplayıcılar ve Ben... İki Yıl Sonra adlı filminden öğreniyoruz (Varda, 2002: 08:53 - 08:56).
} 
birileri ona bahsetmiștir ve bir aracı sayesinde randevulaşıp buluşur. Birlikte kentte dolaşırlar ve Francois ona çöplerden nasıl yiyecek bulduğunu gösterir. Solomon muhtemelen denk geldiği ve peşine takıldığı bir sosyal karakterdir. Pazar yerlerinde bulduklarını orada yiyerek beslenen genç adamla ise pazar dağıldıktan sonra haftalarca küçük el kamerasıyla yaptığı çekimler esnasında tanışır. Her karşılaşmalarında ona bir soru sorarak ilişki kurar ve onun güvenini kazanır. Sonuç olarak Varda, mecburiyetten ve/ya bir tavır olarak pazar yerlerinden ve/ya çöp kutularından beslenmek durumunda olan bu yoksul ve muhtaç sosyal aktörlerin kendilerini ifade etmeleri için onlarla ilişki kurmaya çalışır ve sözü öncelikle onlara bırakır. Kırsal alanda, hasat sonrası tarlada kalanı eğilip toplayanları; bahçelerde, bağlarda dalından koparanları; kentte, pazardan arta kalanlar arasından yenebilecekleri seçenleri; çöpleri karıștırıp arasından ișe yararları alanları; atılan eşyalardan kurtarabildiklerini kurtaranları belli bir mesafeden tesbit ettikten sonra, onlara hassasiyet ve temkinle yaklaşarak, onlarla tanışır. Onlara açık ve gerçek sorular sorarak diyaloğa girer. Her bir sosyal karakteri anlamaya gayret eder. A(r)tık toplayıcıların mağduriyetine neden olan kapitalist pazar ekonomisinde yapılan düzenlemelerinin içyüzünü açığa çıkarıp mağdurların güçlendikleri bir var olma aralığında onlarla kameranın ilişkisini kurgular. Böylelikle, a(r)tık toplayıcılık yapmak durumunda kalan mağdurlar kapitalist düzenin ișleyişini açık ederek, a(r)tık toplayıcılığının onları güçlü kılan yanıyla seyircinin karşısına dikilir, düzene dair bilinçlerini ve mücadele etme biçimlerini ortaya koyarlar. Böylelikle Varda, sineyazısı içinde her bir sosyal karakterin, kendi biricikliği ile filmde bir yere, sekansa sahip olması için fragmanlar inşa eder. Sosyal karakterlerin kendilerini ifade ettikleri bu fragmanları anlamsal bütünlüklerini bozmadan fimin dokusu içine yerleştirir.

Varda, filmin üretim sürecinde, ihtiyacı olmadığı halde toplayıcılık yapan sosyal karakterlerle de karşılaşır, tanışır. Kendine sorduğu ve bize yönelttiği soru açıktır: Maddi olarak yoksulluk, düşkünlük, muhtaçlık içinde olmadığı halde toplayanlara a(r)tık toplayıcı diyebilir miyiz? Onların durumunu açığa kavuşturduğu sahne, hukukçu dostunun lahana, domates tarlalarında gezerek Varda'ya verdiği mülakattadır. Hukukçu, ceza yasasının ilgili maddesine göre, toplayıcılığa gün doğumundan gün batımına dek müsade edildiğini belirtir. $\mathrm{Bu}$ toplayıcılığın ilk yasal koşulu olarak geçer. İkinci koşulsa toplayıcılığın hasattan sonra yapılmasıdır. Hukukçu geriye dönük olarak içtihatları karıştırırken 1554 tarihli bir ferman bulduğunu ve bu fermanda da benzer ifadelere yer verildiğini söyler (Varda, 2000a: 28:43 29:57). Varda sorar, "Eski belgeler yoksullardan, muhtaçlardan bahsediyor ama toplayıcılıktan hiç bir şey beklemeyen ve bunu sırf eğlencesine yapanları hangi kefeye koyacağız?" Hukukçu cevap verir: "Sanki bir şeyin ihtiyacı içindeler. Eğlencesine toplayıcılık yapıyorlarsa, eğlenmek istediklerinden dolayıdır. Zamanı ve şartları göz önünde bulundurursak yoksulların yaptıkları gibi toplayıcılık yapabilirler" (Varda, 2000a: 29:58 - 30:20). Bu bağlamda, Varda bir yanda atıklarla sanat eseri üreten sanatçıların, diğer yanda fırtına sonrası kıyıya süreklenen istiridyeleri toplayanların, terk edilmiş bir bağın hasadını yapan bir ailenin toplayıcılığını anlamaya ve anlatmaya çalışır. Evet, onlar da toplayıcıdır. Sanatçılar, atıkları eserlerinin materyali olarak kullanarak bir tür geri dönüşüm ve kazanım içindedir. ${ }^{24}$ İstiridye toplayanlar pahalı bir deniz ürününün kolayca toplanabileceği dönemleri, koşulları bekler ve topladıkları istiridyelerin tadını çıkarırlar veya ek gelir sağlarlar. Terk edilmiş bağı hasat eden Nenon ailesi de bağdaki üzümü çürümeye birakmak yerine tüketmek için toplar.

Varda filmine konu olan tüm özneleri rahatsız olmayacakları biçimde filminin içine çekmeye gayret eder. Onların her birine filmi(ni) kurmaları için yer açar. Onlardan kurduğu fragmanları filminin dokusuna uygun biçimde tasarlar ve bir ritim üretecek şekilde filmine yerleștirir. Bu_karakterlerle kurduğu ilişkiler sonucu açığa çıkan görüntülerden kurguladığı

${ }^{24} \mathrm{Bu}$ konuda daha fazla bilgi edinmek için şu yüksek lisans tezine bakabilirsiniz: İlhan, M. (2016). Transforming Trash as an Artistic Act (Basılmamış yüksek lisans tezi). İ.D. Bilkent Üniversitesi, Ankara. 
hikayeleri topladığı bütünsel bir film oluşturur. Peki, Varda seyircisinden ne bekler?

\section{Varda Seyircisini Filmin Parçalarn Arasındaki Ilişkileri ve Bağlantılar Yeniden Üretmenin İçine Çeker}

Calatayud (2002), A(r)tık Toplayııılar ve Ben filmini belgesel ile samimi bir portre çalıșması arasında bir yere konumlar. Seyircinin bu filmin içine nasıl çekildiğini ve film içindeki olası ilişkileri nasıl yeniden ürettiğini, bağlantıları nasıl kurduğunu ise şöyle açıklar:

Bu film bir yapboz veya sabır oyunudur; her seyircinin rasgele savrulmuş fragmanları kendince seçmesi ve bu parçaların renk ve dokularının dikte ettiklerine göre bir araya getirmesi beklenir. Böylelikle, farklı parçaların bir araya gelişleriyle yapılanan kaleideskoptan doğru bir çizim oluşmaya başlar. Peyderpey, bağlantılar kurmaya başlarız; ilk olarak Varda' nın birçok kimliği arasında (kadın, eş, anne, sinemacı, toplayıc1), Fransa' da tarlalarda geleneksel artık toplayıcılarla diğer yiyecek arayan kimseler veya kentte atık toplayanlar arasında. Daha birçok bağlantı vardır: klasik müzik ile rap arasında; çamurlu yollar, asfalt yollar, otobanlar arasında; iki ülke (Fransa ve Japonya) arasında; Paris ve Fransa' nın diğer kentleri arasında; sinemanın doğuşundaki ön bilgi (Etienne-Jules Marey ve onun "fotografik-tüfeği") ile ikinci bin yılda film yapma bilgisinin karmaşıklı̆̆ (Varda ve onun küçük dijital kamerası) arasında (Calatayud, 2002: 114).

Calatayud'unişaret ettiği gibi, Varda, filminde seyirciyi farklı temaların, farklı biçimleriarasında ilişkiler aramaya, bağlantılar kurmaya davet eder ama bununla yetinmez. Seyirciden temelde beklenen, ona sunulan parçalar arasında karşılaștırmaya, ilişkilendirmeye dayalı bir okuma yapması iken, seyirci kendi kültürel sermaye birikimi ve kişisel hayat deneyim yığını içinden çok daha farklı ilişkiler, bağlantılar da kurabilir. Filmin parçalardan oluşturulmuş yapısı ve açık uçluluğu -yani çözülüme yönelik, arınmaya (catharsis) dayalı bir finalle sonlandırılmayışıseyirciye öngörülenin yanı sıra kişiselleștirme imkânları sunar. Böylelikle seyirci, pasif ve belli bir mesafede sabitlenen biri olmaktan çıkar; filmin içine çekilir, filmi seyrederken - ve sonrasında-parçaları yineden, yeniden dokuyabilen bir fail haline gelir. Varda, seyircisi ile arasında "tatminkâr bir mübadele" ilişkisi kurma gayretindedir (Conway, 2015: 81).

Chrostowska (2007), eğilerek toplama eyleminin "tutumluluk" yanı sıra "tevazu" da barındırdığını belirtir ve ekler: Toplanan şey bir direnç göstermediği gibi, "olumlu anlamda el altında"dır (ready-at-hand), "toplayıcının dikkatini çekerek alınmayı bekler haldedir" (121). Varda'nın filmine yayılmış farklı konulara ait görüntü ve ses sekanslarının "kendini işaret eden hediyeler" olarak beklemesi gibi (Chrostowska, 2007: 121). Seyirci bu parçaları, aynen bir sineyazar gibi, toplayıp yeniden düzenlemeye davet edilir. Seyirciden beklenen a(r)tık toplayıcının ve sineyazarın tarayan ve araștıran gözleridir. Varda ona belli dokular, izlekler, örüntü alternatifleri sunmuş olsa da, seyirci bulduğu her şeyi nasıl bir araya getireceğinde görece serbesttir. Yine Chrostowska' ya göre (2007), Varda, filmin temel meselesini ele alırken kameranın önünde ve arkasında varlığını açık biçimde hissettirerek "öznel bir dürüstlük aurası" yaratmakla kalmaz, bu yolla seyircisinin yerleşik film seyretme alışkanlığı içinde kendinden geçmesine müsade etmez, seyircisini ele aldığı meseleye dair ayık tutar (130).

Aydan Özsoy (2018) ise, Varda'nın “deneyimlerini seyirci ile paylaşma ve tartışma arzusu" içinde sinema yaptığının altını çizer (376). Bu anlamda, A(r)tık Toplayıcılar ve Ben filmi bir yandan seyircisini ele aldığı meseleye dair ayık tutarken, diğer yandan seyircisiyle diyaloğa girer; seyircisiyle ortaya koyduğu fikir ve duyguları tartışmak ister. Seyircisini, kendisine aktarılan meseleyi kendi üzerinden geçirerek kendini sorgulamaya, ortaya konan israf meselesi üzerine düşünmeye iter... Bu bağlamda, Varda'nın seyircisiyle kurduğu ilişki, John 
Berger' in okuruyla kurduğu ilişkiyi hatırlatır. John Berger'in konuşmalarında tekrarladığı bir izlek, okuyucusuna metinlerinde yer açma gayretidir. Okurunun okuma edimi içinde metnin ortak-yazarı haline gelmesinin temel gayelerinden biri olduğunu söyler. ${ }^{25}$ Agnès Varda'nın A(r)tık Toplayıcılar ve Ben filminde benzer bir gayret içinde olduğu hissedilir. Yani, Varda da, Berger'in kitaplarında yaptığ 1 gibi, seyircisini A(r)tık Toplayıcılar ve Ben filminin seyri esnasinda ve sonrasinda (sinema salonundan ayrıldıktan sonra ve ilerleyen zamanlarda filmi hatırladıkça) bir fail olarak filmi yeniden üretmeye davet eder, hattâ biraz da zorlar.

\section{Sonuç}

Buraya kadar, Agnès Varda'nın A(r)tık Toplayıcılar ve Ben filminin-zaman zaman filmografisindeki diğer filmlerine de referans vererek - seyri esnasında ve sonrasında (sinema salonundan ayrıldıktan sonra ve ilerleyen zamanlarda filmi hatırladıkça) seyircisinin yaşam gücünü artırma niteliğini ortaya çıkaran kaynaklardan tesbit edebildiğim üçünü inceledim. Hatırlayacak olursak, bunlar Varda'nın bu belgesel filminde kendini “a(r)tık/görüntü toplayıcı kadın sinemacı" olarak konumlaması; yaşamı boyunca sürekli geliştirdiği ve cinécriture (sineyazı) olarak adlandırdığı sinema yapma biçiminin kurucu nitelikleri; filminin özneleri ve seyircisiyle kurduğu özgün ilişkilerdir. Şimdi, bu makalenin sonucu olarak, sırasıyla bu kaynakların seyircinin ve kısmen de filme konu olan öznelerin yaşam gücünü nasıl artırdıklarını tartışacağım.

\section{Varda'nın Filminde Kendini Konumlayışı}

Varda, filmine konu olan a(r)tık toplayıcı öznelere benzer bir biçimde kendini filminde konumlandırır ve filmine dahil eder: Bir a(r)tık görüntü toplayıcısı olarak, hem önceki filmlerinin hasadı sonrası artan ve arşivinde biriken görsel-işitsel materyali yeniden kullanır, hem de sinema sanayinin sektörel kalite standartları dışında kaldığı için çöp saydığı atık görüntüleri değerlendirir. Yaşamın birçok alanında olduğu gibi, sinemada da israfın büyüyerek yayıldığı, çöpün heryeri kaplamaya başladığı bir çağda, sinema yapabilmek için a(r)tıklarla çalışmayı öğrenir. Ömrünü sinemasının şeklini arayarak geçiren bir yönetmen olarak a(r)tıkları değerlendirme, yeniden kullanım, geri dönüşüm Varda' nın sinemasını özgünleştirir. Diğer bir bakış açısından söyleyecek olursak, popüler sinemanın büyük ölçekli üretimi dışında, star sistemine dahil olmadan, kendi mütevazı işini yapabilmek için Varda' nın başvurduğu üretim biçimlerinden biri de daha önce ürettiği filmik materyalin geri dönüşümü, yeniden kullanımı ve değerlendirilmesidir. Öte yandan Varda' nın a(r)tık toplayıcılı̆̆ını yalnızca filmik materyale indirgemek eksik bir saptama olur. O filmik materyali yeniden değerlendirirken metinlerarası ve görselliklerarası bir dokuma yapar; artistik ve politik söylemlerini farklı bir estetik kavrayıșla yeniden üretir. Bu bağlamda, Varda'nın a(r)tık görüntü toplayıcı olması artistik bir tercih olduğu kadar, ekonomi-politik bir pozisyonlanma ve film üretmeyi sürdürebilmek için yaşadığı bir zaruret olarak görülebilir.

Varda, A(r)tık Toplayıcılar ve Ben filmini yaparken profesyonel ekipman kullanım

\footnotetext{
${ }^{25}$ John Berger'in bu izleği tekrarladığı şu konușmalarını izleyebilir, dinleyebilirsiniz: John Berger (2012) "Memory Marathon", Serpentine Gallery: <https:/ / www.youtube.com/ watch?v=aBskZXxpX2k> (08:30-11:48).

John Berger (2015) "Rear Window - John Berger (Writer, Painter, Art Critic", Telesur: < https://www.youtube. com/watch?v=aBskZXxpX2k> (02:36-03:50).
} 
kuralının da dışına çıkar ve yarı profesyonel dijital el kamerası kullanır. ${ }^{26}$ Dijital el kamerasını kullanarak ürettiği düşük kaliteli görüntülerle, 1960'lardan beri video sanatı içinde, ağırlıklı olarak feminist sanatçlar tarafından yeniden üretilegelen video estetiğine yönelmiş görünmektedir. ${ }^{27}$ Bunu $A(r)$ tık Toplayıcılar ve Ben filminde kullandığ dijital el kamerasına dair kurguladığı fragmanda (Varda, 2000a: 04:40-05:52) bize derinden hissettirir. Öte yandan, kadın olmanın yanı sıra, 'yaşlanan bir kadın' olmasından dolayı sinemanın dışına doğru itilmeye direnmek, film yapmayı feminist bakış açısı içinde güçlendirerek sürdürebilmek için de dijital el kamerasına sarılır. Bu kameranın ona sağladığı yenilikçi imkânlarla kadın görüntü toplayıcı olmanın görsel-işitsel politikasını ve poetikasını üretir. Bu biçimde kendini düşünceleri, duyguları ve bedeni ile filme dahil ederken a(r)tık toplayıcılarla benzer bir dünyayı paylaştı̆̆ını bize hissettirir. Bir eliyle diğerini çekerken, doğaçlama konuşmaları içinde feminist bir bilinç akışı yaratır. Yani filme dahil ettiği yalnızca bir üstses olarak kendisi değildir; düşünsel ve duygusal akışları, sayıklamalarıdır.

\section{Varda'nın Sineyazısındaki Yaşam Gücü}

Varda'nın sineyazısının hissettirdiği ilk şey, sinematik olarak ele aldığı meselelerle sahici bir ilişki kurma, bu meselenin kendi yaşamı içindeki karşılığını arama, bilgisini üretme; seyircisini de bu arayıșa ve üretime katma arzusudur. Bu da, hem kendini, hem filmini yaptığ1 konuyu/özneleri, hem de seyircisini (genelleyerek toplumu da diyebiliriz) anlamaya çalışan entelektüel bir bireyin kendini gerçekleştirme gayretidir. Yani, bir sineyazar olarak Varda'nın filmleri meselelerine sıkı sıkı tutunan; bu meseleleri farklı boyutlarıyla aktarmaya çalışan; seyircileri de söz konusu meseleleri anlama, kavrama gayretine zorlayan işlerdir. Sineyazar olarak Varda, Zeynep Dadak'ın (2018) onun için söylediği gibi, “(e)n iyi bildiği şeye de en az tanıdığı yere de aynı merakla bakabilen, seyirciyi arasına katabilen..." bir sinemacı ve görsel sanatçıdır (44).

Varda sinemasinı gerçek dünya üzerine kurar. Filmleri kurmaca veya belgesel olarak tasnif edilse de, tümündeki ortak nitelik yaşadığı zamanın ve mekânın; sineyazısıyla yeniden ürettiği tarihin ve coğrafyanın gerçekleri üzerine olmasıdır. Varda filmik gerçekliği, sinemanın iki temel türü olan kurmaca ve belgeseli birbiri içine geçirerek, her bir türün temel niteliğini diğeri içinde yeniden üreterek, kontrpuan bir anlayışla üretir. Belgesele konu olan sosyal karakterleri oyunculuğa davet ederken, oyuncuları kendi hayatlarını düşünmeye, zamanın gerçekleri içinde kendileri olarak oyunculuklarını gözden geçirmeye zorlar. Filmik anlatı da, oyun(cu) rejimi de gerçek ile kurmaca arasında bir salınımda kalır. Bir noktadan sonra, gerçek ile kurmaca, sosyal karakter ile oyuncu arasındaki farklar öylesine daralır ki, Varda'nın filmik gerçekliği kurmaca ile belgeselin bir aradalığına dönüşür. Sonuç olarak, Varda'nın belgesellerinde sosyal karakterler ve kurmaca filmlerinde oyuncular seyircinin özdeşleşmekten çok karşılaştığı bir sosyal tip olarak, seyirciyi kendi yaşamını gözden geçirmeye yöneltirler. Filmlerine konu olan meseleler, seyircinin içinde yaşadığı zaman ve mekândaki (tarih ve coğrafyadaki) varoluşunu sorgulamasına neden olurlar. Bu bireyin yaşam gücüne doğrudan bir müdahaledir. Söz konusu yönetmen Varda olunca, bu müdahale çoğunlukla yaşam gücünü artırma yönünde olur. Ama tersi de olasıdır ki bu durumlarda, Varda içinde yaşanılan zamanın ve mekânın (tarihin ve coğrafyanın) çelișkilerini, haksızlıklarını, yanlıșlıklarını seyircisinin karşısına dikmeltedir. Seyirciye kalansa bu olumsuz durumla yüzleşmek olur...

Varda, A(r)tık Toplayıcılar ve Ben filmine, bu filmin akış dizgesini kuran tarihsel bir

\footnotetext{
${ }^{26}$ Bugün bu cihazların kaliteleri ciddi anlamda yükseldiği için hem televizyon sektöründe program üretiminde, hem de sinema sektöründe film üretiminde kullanılıyorlar.

${ }^{27}$ Bu yönelimin sonucu olarak Varda, yaşamının son evresinde bir görsel çağdaş sanatçı olarak video yerleştirmeler yapar. Bu video yerleştirmeler galeri ve müzerlerde sergilenir.
} 
hipotezle başlar: Artık toplayıcılık, kapitalizm öncesi evreden başlayarak bugün kapitalizmin aldığ 1 biçime kadar nitelik ve biçim değiștirerek süren bir edimdir. 1554 yılında yayımlanan bir fermanda hasat sonrası tarlalarda kimlerin, hangi koşullarda artık toplayıcılık yapabileceği ifade edilirken, bugün kapitalizmin son evresinde yasalarla düzenlenmiş pazar standartları nedeniyle sağlıklı ve yenilebilir olmasına rağmen, biçimi ve boyutları nedeniyle belli bir aralık dışında kalan ürünler tarlalara geri atılmaktadır. Yenebilecek nitelikte olmasına ve çok sayıda aç insan bulunmasına rağmen tarımsal ürünlerin çürümek üzere tarlalara geri atılmasını nasıl izah edeceğiz? İşte bu soru ve bu soruyu açığa çıkaran traihsel hipotetik dizge hem filmin konu özneleri olan a(r)tık toplayıcıların durumunu anlamak, hem de seyircinin bu soru karşısında ne yapacağını görmek açısından önemlidir. Bu noktada şu soruyu sormaktan kaçamayız: Varda'nın belgeselinin meselesini, metodolojik olarak, tarihsel bağlama yerleştirerek ele alması; tarihsel bir mukayeseye dayanarak bugünü anlama, kavrama gayreti, bu belgesel filmin seyircinin yaşam gücünü artıran kaynaklardan biri olabilir mi? Ben, seyircinin tarihsel bağlam içinde a(r)tık toplayıcılık hakkında bilgilenmesinin yanı sıra, filmin temel meselesine dair tarihsel bağlamda düşünmesinin ve duygularının tetiklenmesinin, bu filmin seyircisinin yaşam gücünü artırmasında önemli bir etken olduğunu düşünüyorum. Bu filmin, seyircisinin bilgi dağarında yaptı̆̆ tarihsel genişleme dönüştürücü bir epistemolojik müdahale olarak görülebilir. Varda, seyircisinin bilgi dağarını genişletirken (ve ona bilgi dağarını sürekli genişletmek zorunda olduğunu hissettirirken) seyircisinin yașam gücünü artırır.

Varda'nın filmine konu olan öznelere de, seyircisine de yaşam gücü vermesini sağlayan sineyazı unsurlarından bir diğeri de, filmini bütünleyici biçimde kapatmaktan uzak durarak yapmasıdır. Varda, açık yapılı bütünsel bir film yapar. Tümleyici/toplamcı (totalizing) bir film anlayışından uzak durur. Tümleyici film anlayışı, sinema içindeki yaygınlığıyla, filmin anlatı parçalarını aritmetik bir yaklaşımla toplanabilecek şekilde uyumlu ve aynı türden olmasına özen göstererek filmin yapılandırılmasıdır. Böylelikle, her bir sahne/sekans, diğerleriyle aynı türden ve dilden olacak, ve sonuç olarak bir toplam, kapatılmış bir bütün ortaya çıkaracaktır. $\mathrm{Bu}$ haliyle, filmin anlatısı belli bir biçimde katılaşır ve farklı okumalara kapanır. Varda'nın bütünsel sineması ise cebire dayalı bir sinemadır. Farklı değişkenlere bağlı film parçaları, karmaşık bir fonksiyonun bileşenleri olarak doğrusal olmayan bir eğri çizerken, seyircinin bu eğriyi kuran parçaların her birinin, filmin herhangi bir anında diğerleriyle nasıl bir ilişki içinde olduğunu düşünmesi, değişkenler arası değişen bağlantı güçlerini gözden geçirmesi, değerlendirmesi mümkündür.

\section{Varda'nın Filmin Konu Öznelerine ve Seyircisine Aktardığı Yaşam Gücü}

Toplumun dışına itilmiş, görmezden gelinen yoksullar, muhtaçlar, düşkünler kadar, toplumun israfa dayalı tüketim ideolojisine karşı çıtı̆̆ 1 için ötekileştirilenlerin yanında, onların tarafında olan Varda, kadın hem de yaşlanan kadın olduğu için toplumun görmezden geldiği, sinema sanayinin gözden çıkarma eğiliminde olduğu bir yönetmendir. Tüm bunların sonucunda, ötekilik pozisyonunu reddetmeden, dünya için doğruyu yaptığının bilincinde filmini yapan, yapılandıran Varda, filminin konu öznesi olan a(r)tık toplayıcılara yaptıklarının utanılacak hiçbir yanı olmadığını ve hatta dünya için doğru bir iş yaptıklarını göstererek yaşam gücü verir. Seyircisine ise, israfa dayalı tüketim üzerinden işleyen düzenin hegemonyasına rıza üretmek durumunda olmadığını, hayatın çok farklı alanlarında direnişi örgütlemenin mümkün olduğunu göstererek onların yaşam gücünü yükseltir.

Özdüşünümselliğin ilk adımı olarak varlığını filme dahil ederken bir yandan kendinin de bir a(r)tık toplayıcı olduğunu ilan eden Varda, diğer yandan seyircisinin de benzer biçimde kendini gözden geçirmesini ondan talep eder. Filmine konu olan öznelerden beklediği samimiyeti ve hakikiliği, öncelikle kendisi seyircisine sunar; bunun karşılığı olarak da seyircinin 
de israfla çöpe boğulan dünya karşısında kendi sorumluluğunun farkına varmasını ister. Seyircinin bu çağrıya verdiği somut cevap, $A(r)$ tık Toplayıcılar ve Ben filminin dünyada yapılan yaygın gösterimleri sonrasında, Varda' ya çok sayıda hediye, mektup, kart yollamasıdır. Varda, bu hediyelerden yola çıkarak A(r)tık Toplayıcılar ve Ben filminin devamı niteliğinde ikinci bir film yapar: A(r)tık Toplayıcılar ve Ben... Iki Yıl Sonra (2002). Sonuç olarak, Varda'nın filmin seyircisine aktardığı yaşam gücü somut üretimlere neden olmuş, seyirci filmin meselesini içselleştirdiğini gösteren hediyeler üreterek Varda ile temasa geçmeye çalışmıştır. Böylelikle, seyirci yalnızca filmin seyri esnasında (ve hatırladıkça sonrasında) filmin parçaları arasında ilişkiler ve bağlantılar kuran bir fail olmakla kalmamış, zaman içinde dünyadaki israfa ve çöpe dair bilincini ortaya koyan üreticiler haline gelmiștir...

Varda, filmin içindeki dramatik anların içeriğinin sertliği karşısında, seyircisine hüzünlenmekten çok sorumluluk alması gerektiğini-hatta bunlardan sorumlu olduğunu ve çözüm bulmakta aktif rol alması gerektiğini-sürekli hatırlatır. Seyirciyi ağır dramatik sahneler ile durumun vehametine uyandırmak beklenenin tam tersi etki yaratarak, seyircinin döktüğü gözyaşlarıyla kendini arındırması ile sonuçlanacağından, seyirciyi bu meselenin ciddiyeti konusunda oyundolu ve hayatı tiye alan espirili bir yaklaşımla arafta bırakır. Seyircinin kendini gözden geçirmesine, kendini yakalamasına, hüzün verici durumdan sorumlu olduğunun farkına varmasına neden olur. Kendini yakalayan seyirci bu meseleyi düşünmek, hayatı içindeki karşılaşmalarda bununla uğraşmak zorunda kalır. Gıcık bir durum, değil mi? Varda' nın seyircisinin üstüne tatlı tatlı gitmesi, espirili yaşam anlayışıyla onu köşeye sıkıștırması, kendisiyle yüzleştirme stratejisi diyebiliriz buna. Sineyazısı içinde, filmlerinde kendisiyle dürüstçe, samimi ve hakiki biçimde yüzleşen Varda, seyircisini de benzer bir durum içine sürükler... Bunlar illa ki seyircinin yaşam gücünü azaltacak ve kederlendirerek onu aşağı çekecek demek değildir. Buradan, tam da mücadele etme kararlılığıyla çıkan, kendi payına düşeni yapmanın sorumluluğunu hisseden seyirci yaşam gücünü artırarak yoluna devam eder...

\section{Kaynakça}

Astruc, A. (1948). The Birth of a New Avant-Garde: La caméra-stylo.

Aytaç, S. (Mart 2018). Söz ve İmge. Altyazı, 181, 46.

Aytür, Ü. (2017). Önsöz. William Faulkner içinde, Çılgın Palmiyeler (ss. 5-16). İstanbul : Yapı Kredi Yayınları.

Bazin, A. (1957). La politique des auteurs. Orjinali şu dergide basılı: Cahiers du Cinema, no. 70. <http://www.newwavefilm.com/about/la-politique-des-auteurs-bazin.shtml>

Bénézet, D. (2014). The Cinema of Agnès Varda: Rsistance and eclecticism. London \& New York: Wallflower Press.

Beugnet, M. (2006). Screening the Old: Femininity as old age in contemporary French Cinema. Studies in Literary Imagination, 39(2) Fall, 1-20.

Calatayud, A. (2002). Les glaneurs et la glaneuse: Agnès Varda's Self-Portrait. Dalhousie French Studies, 61 Winter, 113-123.

Chrostowska, S. D. (2007). Vis-à-vis the glaneuse. Angelaki, 12:2, 119-133. https:// doi. org/10.1080/09697250701755092 

Press.

Conway, K. (2015). Agnès Varda. Urbana, Chicago, and Springfield: University of Illinois

Cruickshank, R. (2007). The Work of Art in the Age of Global Consumption: Agnès Varda's Les Dadak, Z. (Mart 2018). Kisaların Uzun Tarihi. Altyazı, 181, 44.

Flusser, V. (2002). Essays. V. Flusser içinde, Writings (ss. 192-196). Minneapolis/London: University of Minneota Press

Gökçe, Ö. (Mart 2018). Hayat Duygusu. Altyazı, 181, 49.

Göl, B. (Mart 2018). Rüzgârda Dalgalanan Hayatlar. Altyazı, 181, 41.

Guest, H. (July / August 2009). Emotion Picture: Agnès Varda's Self-Reflexive 'The Beaches of Agnès'and The Cinema of Generosity. Film Comment, 44-49. Ayrintı.

Huizinga, J. (2010). Homo Ludens: Oyunun Toplumsal İşlevi Üzerine Bir Deneme. İstanbul:

İlhan, M. (2016). Transforming Trash as an Artistic Act (Basılmamış yüksek lisans tezi). İ.D. Bilkent Üniversitesi, Ankara.

Ildır, A. (Mart 2018). Biri Yolda, Diğeri Değil. Altyazı, 181, 47.

Jackson, E. (2010). The eyes of Agnes Varda: Portraiture, cinecriture and the filmic ethnographic eye. Feminist Review, No. 96, 122-126.

Kline, J. T. (Ed.). (2014). Agnes Varda: Interviews. Jackson: University Press of Mississippi.

McFadden, C. (2014). Gendered Frames, Embodied Cameras: Varda, Akerman, Cabrera, Calle and Mä̈wenn. Madison, Teaneck: Fairleigh Dickinson University Press.

Meyer, A. (2009). Gleaning the Passion of Agnès Varda. İçinde J. T. Kline (Ed.). (2014). Agnes Varda: Interviews (198-202). Jackson: University Press of Mississippi.

Murray, N. (2009). Interview: Agnès Varda. A.V. Club. <https://film.avclub.com/agnesvarda-1798216943>

Onaran, G. (Mart 2018). Sanatçı Varda. Altyazı, 181, 53.

Özsoy, A., (2018). Kadın Gözüyle Mutluluğun Portresi: Agnes Varda'dan Mutluluk. İçinde S. R. Öztürk ve Hasan Akbulut (Ed.), Perdeyi Aralamak: Filmlerde Anlatı ve Eleştiri (369-385). İstanbul: Ayrıntı.

Sarris, A. (2009). Notes on the Auteur Theory in 1962. İçinde L. Braudy \& M. Cohen (Ed.), Film Theory and Criticism: Introductory Readings (451-454). New York, Oxford: Oxford University Press.

Sellier, G. (2010). Women in the Nouvelle Vague: The Lost Continent? In V. Callahan (Ed.), Reclaiming the Archive: Feminism and Film History (176-192). Detroit, Michigan: Wayne State University Press.

Sönmez, N. (Mart 2018). Agnés Varda: Bir Sinema Maceraperesti. Altyazı, 181, 38-40.

Trilling, D. (29 Mart 2019 güncelleme). At home (and away) with Agnès Varda. <https:/ / www.bfi.org.uk/news-opinion/sight-sound-magazine/interviews/home-away-agn-svarda>

Tyrer, B. (2009). Digression and return: Aesthetics and politics in Agnès Varda's Les Glaneurs et la glaneuse (2000). Studies in French Cinema, 9(2), 161-176. 
Varda, A. (2000a). Les glaneurs et la glaneuse [Sinema Filmi]. Fransa: Ciné Tamaris.

Varda, A. (2000b). The Gleaners and I Press Kit. New York: Zeitgeist Films. <https:// zeitgeistfilms.com/media/films/44/presskit.pdf>

Varda, A. (2002). Les glâneurs et la glâneuse, deux ans apres [Sinema Filmi]. Fransa: Ciné Tamaris.

Wollen, P. (2004). Sinemada Göstergeler ve Anlam. İstanbul: Metis. 